\title{
IMMIGRATION AND VOTING FOR THE FAR RIGHT
}

\author{
Martin Halla \\ University of Innsbruck
}

\section{Josef Zweimüller}

University of Zurich

\author{
Alexander F. Wagner \\ Swiss Finance Institute - University \\ of Zurich
}

\begin{abstract}
Does the presence of immigrants in one's neighborhood affect voting for far right-wing parties? We study the case of the Freedom Party of Austria (FPÖ) that, under the leadership of Jörg Haider, increased its vote share from less than $5 \%$ in the early 1980 s to $27 \%$ by the end of the 1990 s and continued to attract more than $20 \%$ of voters in the 2013 national election. We find that the inflow of immigrants into a community has a significant impact on the increase in the community's voting share for the FPÖ, explaining roughly a tenth of the regional variation in vote changes. Our results suggest that voters worry about adverse labor market effects of immigration, as well as about the quality of their neighborhood. In fact, we find evidence of a negative impact of immigration on "compositional amenities". In communities with larger immigration influx, Austrian children commute longer distances to school, and fewer daycare resources are provided. We do not find evidence that Austrians move out of communities with increasing immigrant presence. (JEL: P16, $\mathrm{J} 61)$
\end{abstract}

The editor in charge of this paper was M. Daniele Paserman.

Acknowledgments: We thank the Editor M. Daniele Paserman and four anonymous Referees for excellent comments that significantly improved the paper. We thank Statistics Austria for providing the census data. For helpful discussions and comments we thank Stefan Bauernschuster, David Card, Albrecht Glitz, Michel Habib, Helmut Rainer, Friedrich Schneider, Davide Ticchi, Andrea Weber, Hannes Winner, Rudolf WinterEbmer, and participants of several conferences, seminars, and workshops. We thank Thomas Schober for excellent research assistance. This research was funded by the Austrian Science Fund (FWF): National Research Network S103, The Austrian Center for Labor Economics and the Analysis of the Welfare State; the NCCR FINRISK and the UHZ RPP Finance and Financial Markets. Previous versions of this paper were circulated under the titles "On the Political Implications of Immigration" and "Does Immigration into Their Neighborhoods Incline Voters Toward the Extreme Right? The Case of the Freedom Party of Austria." Halla is a Research Fellow at IZA; Wagner is a Research Fellow at CEPR and a Research Associate at ECGI; Zweimüller is a Research Fellow at CEPR, CESifo, and IZA.

E-mail: martin.halla@uibk.ac.at (Halla); alexander.wagner@bf.uzh.ch (Wagner);

josef.zweimueller@econ.uzh.ch (Zweimüller) 


\section{Introduction}

Voters in many European countries-including Austria, Belgium, Denmark, France, Germany, Netherlands, Norway, Switzerland, and the United Kingdom-have expressed strong support for far-right and right-wing populist political parties in recent elections. This is a noteworthy change compared to the 1970s until the mid-1980s, when hardly any far-right party had gained more than 5\% in a general election. Economic policy is shaped by these parties. Moreover, some of these parties have extreme tendencies. History reminds us that the rise of extreme parties within a democratic environment can put democracy itself at risk (Almond and Verba 1965; Dahl 1989). Explaining the success of far-right parties is, therefore, clearly an important issue.

Although far-right parties are quite heterogeneous, they share a number of ideological features (Mudde 1996). In particular, they all have fierce anti-immigration programs, which often become their main focus. Thus, immigration is a natural candidate for explaining the success of these parties. At the time of this writing, an unprecedented inflow of immigrants into Europe is occurring. It is unlikely that this inflow is going to stop on its own. Instead, limits on immigration are now widely discussed and partially implemented. Casual observation suggests that far-right parties throughout Europe are at least temporarily benefiting from voters' worries regarding this inflow. This casual observation on current events is supported by suggestive historical evidence, presented in Figure 1, which suggests a positive relationship between the share of immigrants in a population and the support for far-right parties. Taking country fixed effects into account, the correlation between the immigrant share and the existing far-right vote share is 0.53 . When considering also countries where no far-right parties exist, the correlation is 0.30 .

This paper investigates whether immigration in voters' neighborhoods is a driving force of the rise of far-right parties. Although the cross-country evidence suggests a positive relationship, it may be that enhanced contact with immigrants improves mutual understanding and fosters an appreciation of different viewpoints (Allport 1954). This may lead to a negative relationship between immigration and support for the far right. Understanding the political consequences of immigration is a central prerequisite for the formulation of intelligent policy proposals.

We look at the case of the Freedom Party of Austria (Freiheitliche Partei Österreichs, FPÖ), which generated substantial international attention. Until the early 1980 s, the FPÖ was a small party with a vote share (in elections to the national parliament) of around 5\%. When Jörg Haider became the party leader in 1986, the nationalists within the party, favoring an anti-immigration stance, prevailed over its business-friendly, libertarian wing. A nationalistic and anti-immigration approach has characterized the party's platform ever since. From 1986 onward, the FPÖ steadily increased its vote share and became the country's second-largest party by the end of the 1990s. In the national elections of 1999 the FPÖ gained almost $27 \%$ of the votes. In 2000, the FPÖ joined with the conservative Austrian People's Party (ÖVP) to form a coalition government that was in power until 2006. In 2002, this coalition enacted a set of more restrictive immigration laws (including, for example, requirements that 


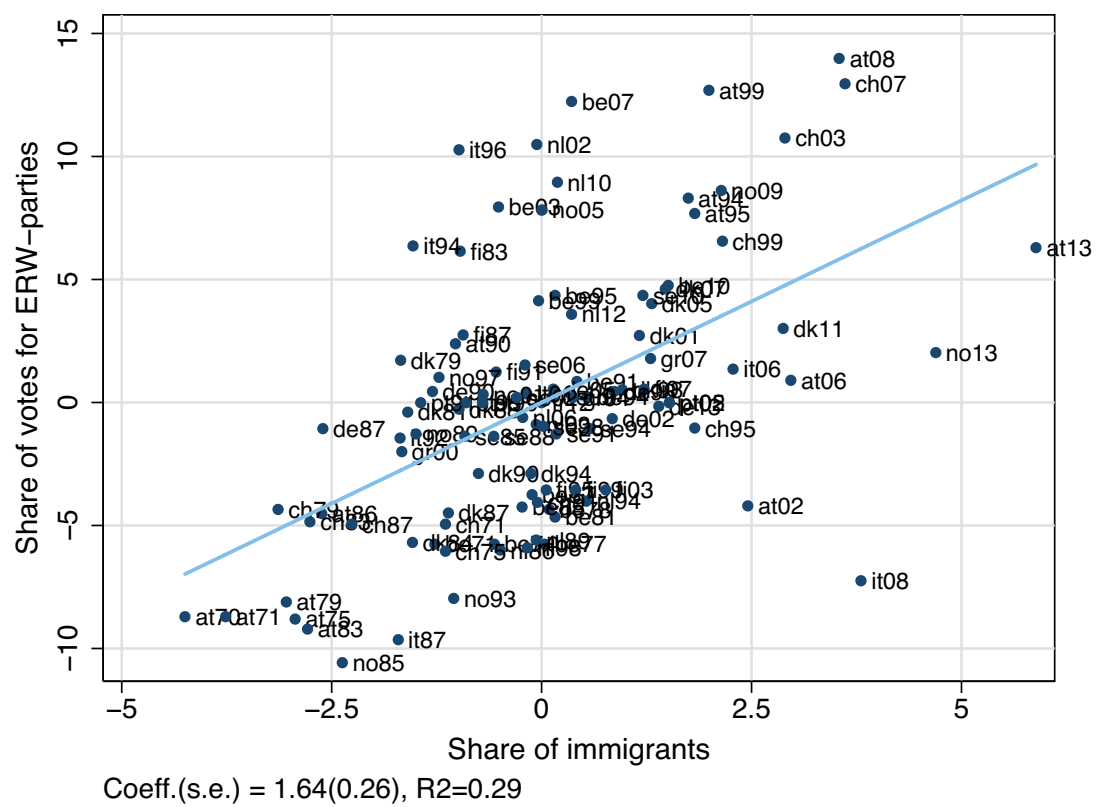

FIGURE 1. Immigration and far-right voting in the EU-15 countries, Norway, and Switzerland, 1970-2013. This scatter plot accounts for country fixed effects (i.e., both variables are centered around the respective country-specific mean) and is based on 103 general election years in EU-15 countries, Norway, and Switzerland in the period between 1970 and 2013; only democratic periods are used. Elections from countries, which do not have any far-right party throughout the whole sample period are excluded. The inclusion of these 33 elections would give the following result: coeff.(s.e.) $=0.53(0.14), R^{2}=0.09$. Sixty-five elections could not be included due to missing information on the number of residents without citizenship in the particular country years. Share of immigrants is defined as the number of residents without citizenship relative to all residents. Data on the total number of residents are from the database of Eurostat. Information on the number of residents without citizenship is from various national sources; details are available upon request. Data on election results are obtained from the Comparative Political Data Set I (23 OECD Countries) provided by Klaus Armingeon, Sarah Engler, Panajotis Potolidis, Marléne Gerber, and Philipp Leimgruber (see http://www.ipw.unibe.ch/research/datasets/index_eng.html). Information on founding years is from Wikipedia.

immigrants study German). Although a heavy election defeat occurred for the FPÖ due to internal conflicts in 2002, and while Jörg Haider died in a car accident in 2008, the FPÖ again became a powerful political force in the 2013 elections with more than $20 \%$ of the votes. In the first round of the Presidential election in April 2016, the FPÖ candidate received the relative majority, $35.1 \%$ of the votes; in the runoff in May, he received $49.7 \%$. However, the constitutional court annulled the result of that election due to irregularities in the vote count in several communities. In the new runoff election in December 2016, the FPÖ candidate received 46.2\%.

To test whether Austrian voters are more or less likely to vote for the FPÖ when there are more immigrants in their neighborhood, we use community-level 
data. Community characteristics are taken from population census data, covering the universe of the Austrian population, thus minimizing measurement problems.

Although it is reasonable to think that more immigrants in one's neighborhood drive anti-immigration sentiments and support for a far-right party, the causality may, in principle, go the other way as immigrants may avoid xenophobic neighborhoods. We begin by establishing that there is no significant relationship between voting outcomes in a community at the beginning of a decade and the ensuing decadal change in the immigrant share. Although this does not eliminate concerns regarding reverse causality, it makes it much less likely that immigrant residential sorting is driven by local support for the FPÖ. Relatedly, we investigate whether initial immigrants' location choices may have been driven by local attitudes toward immigration. We calculate the correlation between the immigrant share in 1971 and a proxy for long-standing antiimmigrant sentiments, namely, the vote shares for the Deutsche Nationalsozialistische Arbeiterpartei (DNSAP, the Austrian counterpart of the German NSDAP) from a 1930 election, the only Austrian election in which the Nazis participated. We do not find a significant relationship, consistent with the idea that local attitudes toward immigration are not prime determinants of immigrants' location choices.

We then use two approaches to investigate the impact of immigration (in the primary analysis: the share of residents without Austrian citizenship) on the FPÖ's vote share in a community. We use panel regressions with community fixed effects to eliminate unobserved time-invariant heterogeneity and thus focus on the impact of the change in immigration on the change in voting outcomes. We also provide complementary evidence using instrumental variables regressions in changes, using immigrants' historical residential patterns as a source of exogenous variation.

Our baseline fixed effect estimate suggests that immigration has an economically important and statistically significant effect on right-wing voting. A one percentagepoint increase in the immigrant percentage in a community increases the FPÖ vote share in the community by about 0.16 percentage points. This implies that a onestandard-deviation increase in the local share of immigrants is associated with a 0.11 standard-deviation increase in the FPÖ vote share. These results are obtained controlling for a range of community factors, such as industry structure, labor market conditions, and demographic and socioeconomic characteristics. Interestingly for the current policy debate, we do not identify an immigration level where the effect on FPÖ votes levels off, nor do we find evidence of "tipping points".

Investigating the channels behind the association of immigration and voting results, we establish the following further results. We document that low- and medium-skilled immigration causes Austrian voters to turn to the far right, whereas more high-skilled immigration either has an insignificant or a negative effect on FPÖ votes. We also find that the effects of immigration are stronger where unemployment among natives is high; where labor market competition between natives and immigrants is strong; where natives are highly educated; and where there are many immigrant children. Moreover, we provide suggestive evidence that immigration may have negative consequences for the quality of schooling and the availability of childcare. Taken together, the evidence is consistent with the idea that natives worry both about detrimental labor market 
outcomes and about negative externalities of immigration on compositional amenities, and that these worries are important drivers of anti-immigrant sentiments and support for the FPÖ.

Finally, we repeat the analysis with an instrumental variable (IV) approach. This is an important complement to the fixed-effect approach because there may be unobserved factors that attract immigrants but also boost FPÖ support. We rely on specific features of the history of immigration into Austria and the resulting historical settlement patterns. Historical immigrant settlement patterns have been used as the basis for IVs in various labor economics settings (see, for instance, Altonji and Card 1991; Card 2001; Dustmann, Fabbri, and Preston 2005; Saiz 2007; Cortes 2008). In Section 5, we argue that, in the present setting, this is a useful approach because, arguably, the allocation of early immigrant cohorts was mainly driven by institutional idiosyncrasies. Drawing on different inflows of immigrants into Austria at different points in time, we compute changes in the "supply-push" component of immigration into communities from one census year to the next.

The advantage of the IV approach is that it identifies a causal effect of immigration on FPÖ votes by exploiting exogenous variation generated by historical immigrant networks. One limitation of the IV approach is a weak first stage when the change in immigration is measured as the percentage-point increase in the share of immigrants in the community population. However, the IV works very well when the change in immigration is measured in percent changes of the immigrant share (and when, therefore, the dependent variable is the percent change of the FPÖ vote share). Although the percent-change specification may lead to different quantitative predictions away from the mean, we verify that this is not a major problem in the present application: For the OLS fixed effects setting, we show that percentage-point and percent-change specifications yield very similar predictions for a broad range of immigration levels and FPÖ vote shares.

Overall, the results of the two empirical approaches, OLS fixed effects and IV, yield similar inferences. In particular, depending on the specification, a one-standarddeviation increase in the local share of immigrants is associated with a $0.08-0.14$ standard-deviation increase in the FPÖ vote share. We also find quite similar results as in the fixed effects OLS regressions in terms of the relevance of the labor market and compositional amenities channels.

Three guideposts can be used to put this analysis into the context of the existing literature.

First, our analysis is related to a rich literature studying political preferences and attitudes toward immigration. ${ }^{1}$ This literature is typically based on survey data, and

1. For studies on attitudes toward immigration see Card, Dustmann, and Preston (2012), Dustmann and Preston (2004), Dustmann and Preston (2007), Facchini and Mayda (2009), Hainmueller and Hiscox (2007), Hainmueller and Hiscox (2010), Krishnakumar and Müller (2012), O'Rourke and Sinnott (2006), and Scheve and Slaughter (2001). For studies related to preferences for political parties and/or policies, see Citrin, Green, Muste, and Wong (1997), Dahlberg, Edmark, and Lundqvist (2012), Dülmer and Klein (2005), Knigge (1998), and Lubbers and Scheepers (2000). 
only little evidence exists, which studies attitudes toward immigration as revealed in elections outcomes. Hence our results are complementary to the attitudes toward immigration literature by studying to which extent support for the far right is related to the presence of immigrants. ${ }^{2}$

The first published study on potential causal political consequences of broad-based immigration $^{3}$ is Otto and Steinhardt (2014), who examine the case of Hamburg. They also first provide evidence of a positive impact of immigration on right-wing voting by conducting fixed effects estimation, and they then rely on lagged immigration shares as an instrument for the future level of foreigner shares. They conclude that labor market effects are unlikely to explain their results and instead argue that voters were concerned about welfare and compositional amenities. More recently, several contemporaneous papers (presented here in alphabetic order) provide further evidence of the effects of immigration. Barone et al. (2016) document a positive impact of immigration into Italian municipalities on center-right voting. ${ }^{4}$ They also provide evidence that both the labor market channel and the compositional amenities channel may be at work driving Italian voters to center right. The most immediate difference in our studies is that our focus is on far-right voting. Moreover, we have access to complete time-varying census data and a very large set of control variables. Brunner and Kuhn (2014) look directly at votes on immigration policies, rather than voting outcomes. Although our measure of political consequences - the overall vote share of the far right-is necessarily more noisy (which ex ante makes it less likely to find effects), our study has the advantage that it sheds light on a source of the overall political power of the far right. Studying the case of Denmark, Harmon (2015) argues that the share of high rise buildings in a municipality in 1970 provides a valid instrument for the increase in ethnic diversity from 1981 to 2001, which is in turn associated with more votes for the extreme right. His analysis is richer than ours in terms of the consideration of vote outcomes also for other parties. On the other hand, because we utilize a much larger number of communities (roughly 2,000 communities compared to 275 Danish municipalities), we are able to document that it is indeed immigration into one's neighborhood that matters, and we are able to explore cross-sectional heterogeneity, thus shedding light on the channels of the connection between immigration and far-right voting. Mayda, Peri, and Steingress (2015) study immigration to the United States, where, contrary to the case of Austria and other European countries, naturalization is frequent, allowing

2. Several studies in the political science literature provide suggestive evidence; see, for example, Arzheimer and Carter (2006), Arzheimer (2009), Golder (2003), Jackman and Volper (1996), Knigge (1998), and Lubbers, Gijsberts, and Scheepers (2002).

3. Other studies, for example, Gerdes and Wadensjö (2008), rely on arguably random assignment of refugees in Denmark. They find that both anti-immigration parties and a left-wing proimmigration party benefit from immigration.

4. They use a historical settlement pattern instrument and argue that initial settlement patterns in 1991 were unaffected by political considerations because the parties they consider for their dependent variable started appearing only after 1991. 
for a separate analysis of naturalized immigrants and noncitizen immigrants. They find that in general Democrats benefit from immigration, but that this can tip into support for Republicans at high immigration levels. Steinmayr (2016) provides evidence that the presence of asylum seekers (i.e., the extensive margin, not the share of immigrants) reduced FPÖ votes in two recent state elections in Austria. Finally, there are some studies that highlight some specific channels that also play a role in our analysis. For example, Malgouyres (2014) identifies in French community-level data a relationship between low-wage country imports competition on the local vote share for the Front National.

In sum, each study has its unique features. In addition to the substantial differences in the approach of investigating effects on elections, an important distinction of our work relative to all these papers is that we study real effects of immigration on compositional amenities, provide differentiated evidence of internal migration patterns, and consider the possibility that historical attitudes may be associated with immigrant sorting. Collectively, these papers and ours make a strong case that immigration and political outcomes are linked.

Second, our work is related to the literature that studies the political economy of immigration policies. Even in countries where so far no important far-right parties have emerged, immigration policies have been strongly shaped by politicoeconomic considerations. ${ }^{5}$ Immigration is an issue with a particularly thin line separating pragmatic economic policy from dogmatic political economics. Anti-immigrant politics may have ideological sources, but politicians may also supply xenophobia because they find it instrumental in discrediting political opponents whose policies benefit immigrants (Glaeser 2005).

Third, this paper adds to more general work showing that economic and social considerations can help explain voting patterns for parties on the extremes of the political spectrum. Much as economic concerns led many voters to turn to the Nazis (King et al. 2008), so have overall economic conditions played a role in the rise of extreme parties in many countries at the beginning of the 20th century (de Bromhead, Eichengreen, and O'Rourke 2013). It is also related to the literature on vote and popularity functions (Nannestad and Paldam 1995).

The remainder of this paper is organized as follows. Section 2 describes the political background of Austria and the data used for our analysis. Section 3 investigates whether election outcomes predict the consequent inflow of immigrants into a community and whether immigrant location is determined by long-standing political preferences of a region. Section 4 presents the empirical results for the impact of immigration on voting and the availability of compositional amenities obtained from panel fixed effects regressions. Section 5 presents results from an instrumental variables approach. Section 6 concludes.

5. See, for example, Facchini, Mayda, and Mishra (2011) and Facchini and Steinhardt (2011). 


\section{Background and Data}

\subsection{Immigration and the FPÖ}

We begin with an examination of the aggregate time-series pattern of immigration and FPÖ vote shares; see Figure A.1 in Online Appendix A. In 1961, only 1.4\% of the resident Austrian population were foreign citizens. Due to the guest-worker programs and the ensuing influx of further immigrants, this share had almost tripled by 1981. In response to emerging problems in the labor market, the Austrian government enacted the Aliens Employment Act (1975), which regulated immigration and reduced the influx of foreign workers. This resulted in a period of return migration and a temporarily stagnating immigrant share. From 1981 to 2001, the share of immigrants more than doubled again, from $3.9 \%$ to $8.7 \%$, with much variation across communities. Turkey and (former) Yugoslav are the two most important sending countries. In 2001, 63.2\% of the total foreign resident population came from former Yugoslavia $(45.3 \%)$ and Turkey (17.9\%). The majority of immigrants from Turkey are Muslim. Immigrants from (former) Yugoslavia comprise Muslims, Orthodox Christians, and Catholics.

The immigration wave of the late 1980s coincided with the rise of the FPÖ. ${ }^{6}$ After Jörg Haider took over leadership of the FPÖ in 1986, the party increasingly invoked the "dangers" to the native population of immigration in terms of crime, unemployment, and decay of neighborhoods and schools. Until 1986, the FPÖ had not played a significant role in national elections (despite having been a junior partner in a government coalition). In the national elections of 1986, however, the FPÖ attracted $9.7 \%$ of the votes. Thereafter, support for the FPÖ grew at a steady rate, passing the 15\% and 20\% thresholds in 1990 and 1994, respectively, and reaching more than 25 in the late 1990s. The development was accentuated by an additional immigrant wave during the Yugoslavian political crisis in 1990 and the war in 1992.

In 1993, the FPÖ launched an "Anti-Foreigner Referendum", and 416,531 Austrian voters (7.35\% of the electorate) approved this referendum. The cross-district correlation between the support for this referendum and the share of votes for the FPÖ in the national parliamentary elections in October 1994 is 0.83 . More generally, in the election years that we study, the FPÖ is widely recognized as having the most restrictive immigration policy platform, whereas the main competitors, the Social Democratic Party of Austria and the Austrian People's Party had a much softer stance. In short, it is clear that a vote for the FPÖ represents a vote against immigration. ${ }^{7}$ Internal

6. We emphasize that other events also took place in that time period. For example, the Austrian political landscape in the 1990s was also characterized by a general dissatisfaction with the governing parties. The Social Democratic Party of Austria and the Austrian People's Party had been governing as a grand coalition since 1987. We include time fixed effects in our analysis.

7. This is not to say that the other parties were completely passive. Under political pressure of increased anti-immigration sentiments, and partly as a reaction to the FPÖs anti-immigration activities, the Austrian 
problems in the FPÖ arose soon after they had become a governing party. As a result of these disputes a new splinter party, the Alliance for the Future of Austria (BZÖ), was established in 2005. After the internal problems were resolved, the FPÖ re-gained strength and obtained a $20.5 \%$ vote share again in $2013 .{ }^{8}$ In the first round of the Presidential election in April 2016, the FPÖ candidate received the relative majority, $35.1 \%$ of the votes. In the runoff election in December, he received $46.2 \%$ of the votes. No significant far left-wing party emerged in Austria during this period.

We note that Austria does not automatically confer citizenship to individuals born in Austria. Instead, an Austrian-born child must have at least one parent with Austrian citizenship in order to be considered for naturalization. Naturalizations are unlikely to be important for studying the relationship between immigration and voting in Austria. We first note that they imply two countervailing effects. On the one hand, immigrants who receive Austrian citizenship may still be regarded as immigrants by the "original" Austrian population, so that the immigrant share in our data understates the perceived immigrant share in a neighborhood. On the other hand, naturalized immigrants are unlikely to vote for the FPÖ. Second, during the 1970s, 1980s, and 1990 s, the annual rate of naturalizations was between $0.1 \%$ and $0.3 \%$ of the native population in most years. Therefore, disregarding naturalizations is unlikely to be important for our analysis.

Just like in other countries (see the studies cited in the Introduction), survey evidence for Austria yields interesting results. For example, analyzing data from the European and World Values Survey, we find in Online Appendix C that those who prefer that scarce jobs be given to native citizens or who even want a complete halt to labor immigration are more likely to be in favor of the FPÖ, as are those who do not care about the living conditions of immigrants or are not willing to do something to improve these conditions. However, surveys also present some problems, sometimes making it difficult to interpret results. In particular, surveys are not anonymous, and survey respondents are unlikely to answer completely truthfully. ${ }^{9}$

government introduced various new tighter immigration rules during the 1990s. Although Austria's entrance into the EU in 1995 opened the borders to immigration from former EU-15 member states, in 2002, the center-right coalition of the Austrian People's Party and the FPÖ enacted a set of more restrictive immigration laws. These laws included requirements that immigrants study German; restrictions on the temporary workers' ability to obtain permanent residence; and, at the same time, a relaxation of procedures for Austrian firms that were hiring high-skilled immigrants of key importance in certain industries. Further rules were put into place to shield Austria's labor market from excessive immigration from the poor, neighboring, new EU member states after the EU expansions of 2004 and 2007.

8. For consistency, we use the FPÖ vote share as the dependent variable throughout. However, very similar results hold when including the BZÖ, which also is on the far right. This is not surprising as, despite some interim strength, the BZÖ obtained only $3.5 \%$ of the vote and failed to secure a seat in parliament in 2013.

9. For example, according to the European and World Values Survey, done shortly before the 1999 general election, the FPÖ could expect to obtain about $20 \%$ of votes, whereas, in the election, the FPÖ scored about $27 \%$. 


\subsection{Main Variables, Data Sources, and Descriptive Statistics}

To establish a relationship between immigration and far-right voting, we use community-level data. In Austria, a community is part of a political district, which is in turn part of one of the nine federal states. The community is the lowest administrative level. In 2001, Austria encompassed 2,359 communities in 99 political districts. ${ }^{10}$ Vienna is the largest community, with about 1.5 million inhabitants in 2001. For our empirical analysis we divide Vienna into its 23 so-called municipal districts and treat these as separate communities. The smallest community, with 60 inhabitants (in 2001), is Gramais in the federal state of Tyrol. The average community (excluding Vienna) had about 2,800 inhabitants. The number of communities and their territorial boundaries have changed over our sample period. In order to have a balanced panel of communities (and due to some limitations of the industry structure data), we use a modified version of the territorial boundaries of the year 2001, which leaves us with 2,106 communities (including the 23 municipal districts of Vienna). ${ }^{11}$

Data on the percentage of FPÖ votes in elections to the national parliament are available from official statistics issued by the Austrian Federal Ministry of the Interior. ${ }^{12}$ Figure A.2 in Online Appendix A shows the geographic distribution of the share of votes for the FPÖ for six general elections. With the exception of a very strong base of support for the FPÖ in the state of Carinthia (located in the south of Austria where former party leader Jörg Haider was leading the local government) no other particular geographical patterns (over time) are evident.

Our key database for computing the percentage of immigrants and all socioeconomic control variables on the community level is the universe of all individual-level observations from the decennial Austrian censuses (on-site at Statistics Austria). The completeness of the census data affords the great advantage that we can minimize problems of measurement error, an important concern in the literature that studies labor-market effects (Dustmann et al. 2005, p. F329). Census data are available to us in electronic form for 1971, 1981, 1991, 2001, and 2011, but not for earlier years. The Austrian survey census was abolished after 2001 and replace by a registrybased census, also maintained by Statistics Austria. For simplicity, we refer to all data as "census" data. The 2011 data have some limitations. For example, they do

10. Notice that we study the effects of the local (=community) presence of immigrants. To the extent that voters worry about, for example, labor market competition with immigrants in other communities (which may arise if labor markets span multiple communities), or about broader regional issues, additional effects of immigration on voting behavior may occur. To allow for such effects we repeated the analysis using the 99 political districts rather than communities as the unit of observation. The overall results in terms of both magnitude and significance are very similar and available on request.

11. Further merges between communities occurred after 2001. In 2011, there were 1,975 communities. The original version of the paper did not use 2011 community-level data. Because redefining all community boundaries also for prior years would be extremely time consuming, we retained the structure of 2,106 communities for prior years and merged the data obtained later into this existing structure.

12. We focus on federal elections as in Austria the most important aspects of economic policy, including immigration policy, are set at the federal level. 
not contain information on religion. Also, they do not contain information on degrees earned abroad (which introduces measurement error in our skill proxies in that year). However, on balance, the advantages of being able to use another decade of data (which, at least, for the primary analysis is of the same quality as the data for the other years) seem to outweigh the disadvantages.

We do not have census data for each possible election year, so we need to infer the relevant immigrant share (as well as the socioeconomic control variables) in those election years that we wish to analyze. To minimize measurement error, the main analysis focuses on elections that took place at most three years from the time of the nearest census, that is, we consider $t=\{1979,1983,1990,1994,1999,2002,2013\} .{ }^{13}$ We relate the election results of 1979 and 1983 to the 1981 census data. Similarly, the election results of 1990 and 1994 are related to the 1991 census data, the election results of 1999 and 2002 to the 2001 census data, and the election results of 2013 to the 2011 census data. A potential concern is that using election data before a census year exacerbates potential endogeneity problems. As we will document, there is no evidence that election outcomes drive immigrant sorting, but we nonetheless also conduct our analysis using strictly only election years 1983, 1994, 2002, and 2013. We pool the data to construct a panel and include year fixed effects in all regressions (though we also conduct year-by-year investigations in the IV analysis).

In our baseline model, immigrants are residents without Austrian citizenship. We also investigate the extent to which FPÖ voting is driven by particular kinds of immigrants. First, we calculate immigrant shares within education groups based on residents 25 years of age or older. There are four education levels: (i) compulsory schooling, (ii) completed apprenticeship training or lower secondary school; (iii) higher secondary school, and (iv) academic degree. We sort immigrants into two groups, based on their highest attained education level: (i) low and medium education (levels (i) and (ii)); and (ii) high education (levels (iii) and (iv)). Second, we distinguish immigrants by their ethnic origin, estimating separate effects for Muslim, Turkish, and Yugoslav immigrants.

As our standard set of community covariates we use the following variables calculated from census data: the community's number of inhabitants, the number of inhabitants squared, the natives' age-sex distribution (22 groups), the natives' distribution of marital status (i.e., the shares of natives who are single, married, divorced, and widowed), and the natives' distribution of labor market status (i.e., the shares of natives who are employed, unemployed, retirees, children below 15 , student, and others). We define these characteristics with respect to the voting population, since this is the natural definition, given that only Austrians citizens have the right to vote. In addition to the census-based covariates just listed, the standard set of community covariates also includes industry structure, which is calculated share as employment share in 32 sectors from the Austrian Social Security Database. In specifications

13. The elections of 1986, 1995, 2006, and 2008 are not included in the main analysis as they are relatively far from the census dates. 
TABLE 1. Descriptive statistics on variables of primary interest.

\begin{tabular}{lcccccccc}
\hline Election year & 1971 & 1979 & 1983 & 1990 & 1994 & 1999 & 2002 & 2013 \\
\hline \% share of FPÖ votes & 5.49 & 6.10 & 5.03 & 16.68 & 22.81 & 27.39 & 10.23 & 21.28 \\
& $(3.68)$ & $(3.72)$ & $(3.18)$ & $(5.73)$ & $(5.45)$ & $(5.99)$ & $(4.78)$ & $(5.02)$ \\
\% share of immigrants & 2.83 & 3.86 & 3.86 & 6.64 & 6.64 & 8.85 & 8.85 & 11.48 \\
& $(2.56)$ & $(3.75)$ & $(3.75)$ & $(5.41)$ & $(5.41)$ & $(6.30)$ & $(6.30)$ & $(7.71)$ \\
With low and medium skills & 2.72 & 3.17 & 3.17 & 5.32 & 5.32 & 6.88 & 6.88 & 8.30 \\
& $(2.73)$ & $(3.12)$ & $(3.12)$ & $(4.28)$ & $(4.28)$ & $(5.10)$ & $(5.10)$ & $(5.47)$ \\
With high skills & 0.40 & 0.52 & 0.52 & 1.14 & 1.14 & 1.55 & 1.55 & 3.00 \\
& $(0.51)$ & $(0.65)$ & $(0.65)$ & $(1.12)$ & $(1.12)$ & $(1.29)$ & $(1.29)$ & $(2.67)$ \\
\hline
\end{tabular}

Notes: This table summarizes population-weighted means and standard deviations (in parentheses below) for the variables of primary interest based on Austrian community-level data. The share of votes for the FPÖ is from general elections; these figures might differ slightly from official election results due to overseas voters and varying turnout of voters across communities. The share of immigrants (with a certain level of education) is equal to the number of residents without Austrian citizenship (with the respective educational attainment) as a fraction of all residents. Shares by skill are calculated based on residents 25 years of age or older and refer to the highest attained educational degree. Low and medium skills are compulsory schooling, an apprenticeship or a lower secondary school. High education is a higher secondary school or an academic degree. The shares of immigrants on a community-level are available in the years 1971, 1981, 1991, 2001, 2011 (census years). The shares of immigrants in the years 1979 and 1983 are imputed with information from the year 1981, the data in the years 1990 and 1994 are imputed with information from the year 1991, the data in the years 1999 and 2002 are imputed with information from the year 2001, the data in the years 2013 are imputed with information from the year 2011.

without community fixed effects, we included further the following time-constant covariates: federal state fixed effects, the unemployment rate in 1961, and the industry structure in $1973 .{ }^{14}$

Finally, we obtain data on various dimensions related to neighborhood quality and compositional amenities (see Section 4.3).

Table 1 reports descriptive statistics on the main voting and census variables used in the empirical analysis below. As the columns for the individual election years show, substantial cross-sectional variation exists across communities in Austria, both in election outcomes and immigration levels. Unreported results show that communities without any immigrants in 1971 (mostly rural areas) had essentially the same average unemployment rate, in both 1961 and 1971, as those that did have immigrants in 1971.

14. The unemployment rates for 1961, which are available on a political district level as reported by the regional offices of the Public Employment Service Austria. A potential source for unemployment rates on the community level would have been the 1961 Austrian census. However, as confirmed by Statistics Austria, the only published source that lists variables on the community level reports only the sum of the absolute number of employed and unemployed individuals. We do not have data on the industry structure in the 1960s. Therefore, a potential limitation of our control variable is that it does not eliminate any impacts of elements of the industry structure that were simultaneously nonpersistent and correlated with both immigrant allocations in the 1960s and voting decisions in recent years. However, given that we find in the data that the industry structure is very persistent over time, we believe that this is ultimately a minor concern. 


\section{Immigrant Sorting, Past Election Outcomes, and Community Preferences}

Before we start to study the effect of immigration on FPÖ vote, it is useful to address the reverse chain of causality. Do immigrants choose locations based on prior election outcomes and/or based on long-standing preferences of certain communities? If immigrants avoid communities with strong anti-immigrant sentiments, the influx of immigrants into communities should be negatively related to FPÖ vote shares in past elections. To the extent such considerations drive immigrants' location choices, there will be a downward bias in an estimate of the effect of immigration inflows on the rise of FPÖ votes.

To investigate this possibility, we test whether voting outcomes in a community at the beginning of a ten-year (or twenty-year) period predict the ensuing decadal or two-decade change in the immigrant share in that community. ${ }^{15}$ Figure 2 shows the corresponding binned scatter plots. There is no indication that such relationship exists, neither in 10-year nor in 20-year horizon data.

Table 2 presents regression results that control for the standard set of community covariates. These regressions in Panel A (for immigrants generally) confirm the findings suggested by the figures. Panels B and C consider the same issue in the context of immigrants differentiated by skill. Only two estimates are statistically significant, but they are positive, suggesting that, to some extent, high-skilled immigrants enter communities with a high prior FPÖ share. However, the effects are economically very small, implying that a one percentage point increase in the share of the FPÖ leads a one hundredth of a standard deviation increase in high-skilled immigration. All other estimates are insignificant. Thus, again, there is no consistent evidence of sorting based on prior election outcomes.

Our second approach to investigate the role of community preferences for immigrant sorting considers possible long-standing racial prejudices. Several recent papers have argued that there is strong inertia in local beliefs and values (Voigtländer and Voth 2012; Spolaore and Wacziarg 2013). To test for the relevance of this idea in the present context, we use voting results from a 1930 election, the only Austrian election in which the Deutsche Nationalsozialistische Arbeiterpartei (DNSAP, the Austrian counterpart of the German NSDAP) participated. In Table 3, we regress the share of immigrants in the year 1971 on vote shares in the year 1930 for the DNSAP. The unit of observation here is a political district (because communities have changed so much across the 40 years that a close matching is impossible). Although we find a positive correlation between DNSAP voting and FPÖ voting (in line with persistent political preferences), we do not find any significant association between DNSAP votes in 1930

15. In this analysis, to be conservative we use election years before a census year. Qualitatively the same results obtain, however, if we use only election years after a census year, as we do in the regressions where election outcomes are the dependent variable. 

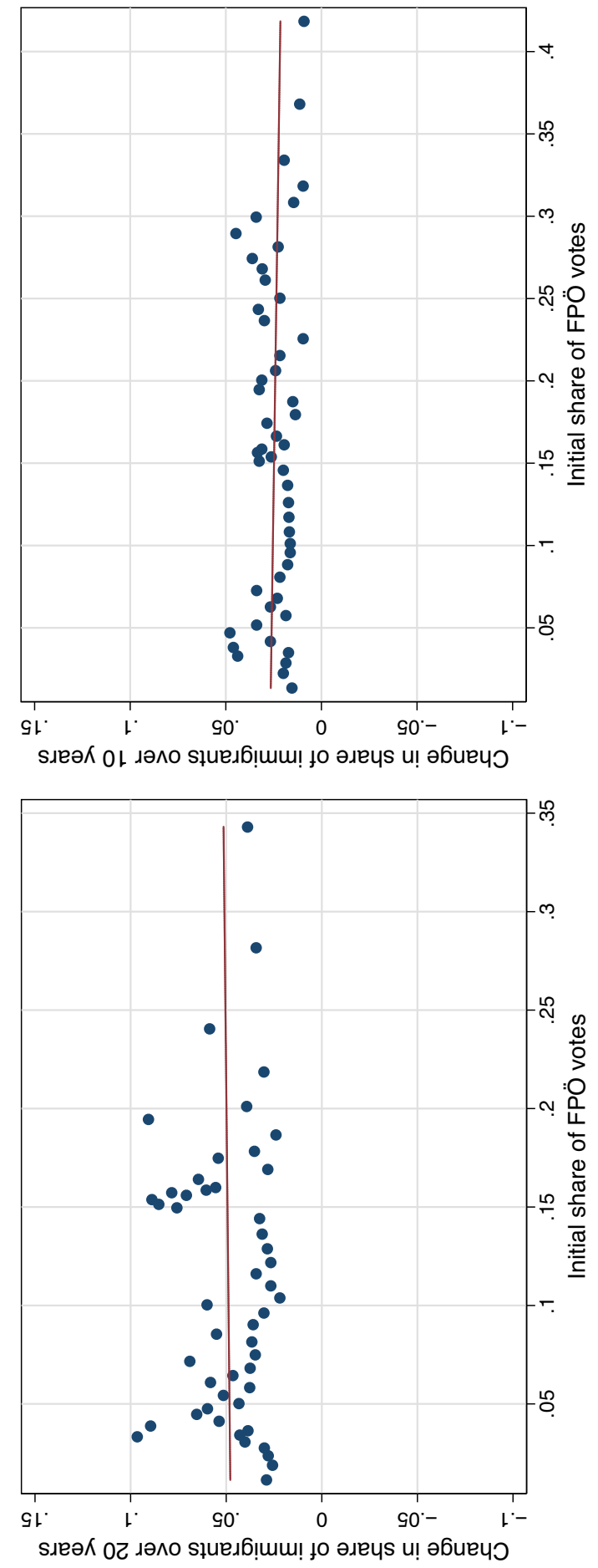

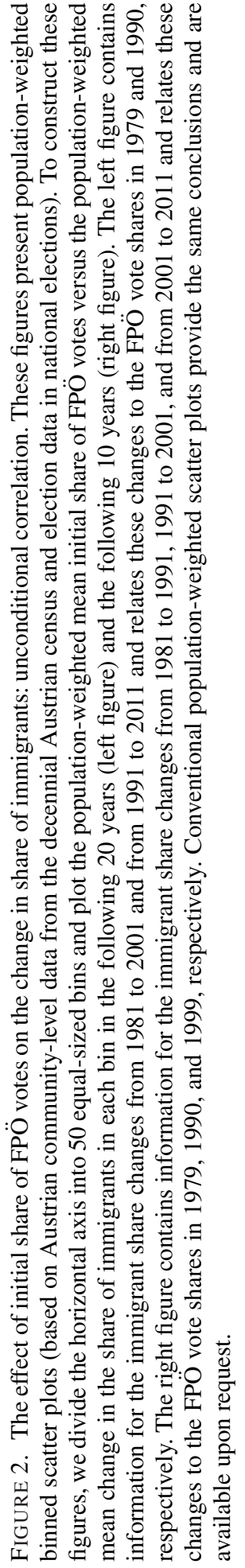


TABLE 2. The effect of initial share of FPÖ votes on the change in share of immigrants.

\begin{tabular}{|c|c|c|c|c|c|c|c|c|}
\hline \multirow{3}{*}{ Dependent variable } & & (1) & (2) & (3) & (4) & $(5)$ & (6) & (7) \\
\hline & \multicolumn{5}{|c|}{$\begin{array}{l}\text { 10-year difference } \\
\text { in share of immigrants }\end{array}$} & \multicolumn{3}{|c|}{$\begin{array}{l}\text { 20-year difference } \\
\text { in share of immigrants }\end{array}$} \\
\hline & & Pooled & $\Delta 11-01$ & $\Delta 01-91$ & $\Delta 91-81$ & Pooled & $\Delta 11-91$ & $\Delta 01-81$ \\
\hline \multicolumn{9}{|l|}{ Panel A: All immigrants } \\
\hline Initial share of FPÖ votes & & $\begin{array}{l}-0.013 \\
(0.027)\end{array}$ & $\begin{array}{l}-0.007 \\
(0.011)\end{array}$ & $\begin{array}{c}0.013 \\
(0.015)\end{array}$ & $\begin{array}{c}0.014 \\
(0.020)\end{array}$ & $\begin{array}{l}-0.007 \\
(0.027)\end{array}$ & $\begin{array}{l}-0.005 \\
(0.020)\end{array}$ & $\begin{array}{l}-0.019 \\
(0.026)\end{array}$ \\
\hline \multirow{5}{*}{$\begin{array}{l}\text { Community charact. }{ }^{\mathrm{a}} \text { in } t_{1} \\
\text { Unemployment rate } 1961^{\mathrm{b}} \\
\text { Industrial structure } 1973^{\mathrm{b}} \\
\text { Community fixed effects } \\
\text { Year fixed effects }\end{array}$} & & Yes & Yes & Yes & Yes & Yes & Yes & Yes \\
\hline & & No & Yes & Yes & Yes & No & Yes & Yes \\
\hline & & No & Yes & Yes & Yes & No & Yes & Yes \\
\hline & & Yes & No & No & No & Yes & No & No \\
\hline & & Yes & No & No & No & Yes & No & No \\
\hline Number of observations & & 6,180 & 1,975 & 2,103 & 2,102 & 4,074 & 1,972 & 2,102 \\
\hline Mean of dependent variable & & 0.025 & 0.022 & 0.023 & 0.028 & 0.050 & 0.046 & 0.052 \\
\hline S.d. of dependent variable & & 0.025 & 0.026 & 0.023 & 0.026 & 0.040 & 0.040 & 0.039 \\
\hline FPÖ votes measured in & 1979 & $9,1990,1999$ & 1999 & 1990 & 1979 & 1979,1990 & 1990 & 1979 \\
\hline Mean of FPÖ vote shares & & 0.165 & 0.273 & 0.167 & 0.062 & 0.113 & 0.168 & 0.062 \\
\hline S.d. of FPÖ vote shares & & 0.101 & 0.061 & 0.058 & 0.037 & 0.072 & 0.058 & 0.037 \\
\hline \multicolumn{9}{|l|}{ Panel B: Low skilled immigrants } \\
\hline Initial share of FPÖ votes & & $\begin{array}{c}0.007 \\
(0.019)\end{array}$ & $\begin{array}{l}-0.005 \\
(0.010)\end{array}$ & $\begin{array}{c}0.014 \\
(0.012)\end{array}$ & $\begin{array}{c}0.006 \\
(0.015)\end{array}$ & $\begin{array}{c}0.003 \\
(0.024)\end{array}$ & $\begin{array}{l}-0.007 \\
(0.016)\end{array}$ & $\begin{array}{l}-0.007 \\
(0.023)\end{array}$ \\
\hline Mean of dependent variable & & 0.017 & 0.011 & 0.016 & 0.022 & 0.033 & 0.027 & 0.039 \\
\hline S.d. of dependent variable & & 0.020 & 0.018 & 0.020 & 0.020 & 0.031 & 0.029 & 0.032 \\
\hline \multicolumn{9}{|c|}{ Panel C: High skilled immigrants } \\
\hline Initial share of FPÖ votes & & $\begin{array}{l}-0.009 \\
(0.007)\end{array}$ & $\begin{array}{c}0.009^{* *} \\
(0.004)\end{array}$ & $\begin{array}{c}0.003 \\
(0.003)\end{array}$ & $\begin{array}{c}0.005 \\
(0.004)\end{array}$ & $\begin{array}{c}0.002 \\
(0.006)\end{array}$ & $\begin{array}{c}0.016^{* * *} \\
(0.006)\end{array}$ & $\begin{array}{l}-0.001 \\
(0.005)\end{array}$ \\
\hline Mean of dependent variable & & 0.008 & 0.014 & 0.004 & 0.006 & 0.015 & 0.019 & 0.011 \\
\hline S.d. of dependent variable & & 0.011 & 0.015 & 0.006 & 0.007 & 0.015 & 0.018 & 0.009 \\
\hline
\end{tabular}

Notes: This table summarizes the estimated effect of the initial share of FPÖ votes on the change in the share of immigrants in the following 10 or 20 years based on a series of weighted (community population weights) OLS estimations with community fixed effects using Austrian community level data. The column header indicates which immigration share difference is used as the dependent variable, and the row "FPÖ votes measured in year" indicates the election year from which the investigation starts. For example, column (7) presents a regression of the change in the share of immigrants in that community from years 1981 to 2001 on the share of FPÖ votes in a community in the year 1979. Columns (1) and (5) pool the respective 10- and 20-year difference regressions. Panel A considers the share of residents without Austrian citizenship. The share of immigrants with a certain level of education is equal to the number of residents without Austrian citizenship with the respective educational attainment as a fraction of all residents. Low and medium skills is compulsory schooling, an apprenticeship or a lower secondary school. High education is a higher secondary school or an academic degree. The shares of immigrants on a community-level are available in the years 1971, 1981, 1991, 2001 , 2011 (census years). Robust standard errors (allowing for clustering on the community and census year levels and/or heteroskedasticity

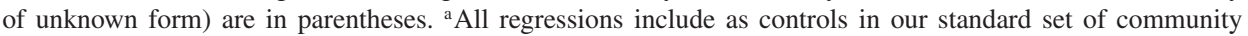
covariates: (1) each community's number of inhabitants (and its square), (2) the distribution of the labor market status (share of inhabitants who are employed, unemployed, retired, or a child), (3) the industry structure (31 variables that capture the share of workers employed in a certain industry relative to the sum of all workers in a given community), (4) the distribution of marital status (share of inhabitants who are single, married, divorced, or widowed), (5) and the population's age-sex distribution. ${ }^{\text {b}}$ The unemployment rate in 1961 and the industry structure in 1973 are time invariant and are, therefore, included in year-by-year regressions only. ** Significant at $5 \% ; * *$ significant at $1 \%$. 
TABLE 3. The share of immigrants in 1971 as a function of votes for the DNSAP in 1930.

\begin{tabular}{|c|c|c|}
\hline & (1) & (2) \\
\hline Share of votes for DNSAP & $\begin{array}{l}-0.001 \\
(0.068)\end{array}$ & $\begin{array}{l}-0.034 \\
(0.065)\end{array}$ \\
\hline Vienna & Yes & Yes \\
\hline Carinthia & Yes & Yes \\
\hline Inhabitants 1971 & No & Yes \\
\hline No. of observations & 111 & 111 \\
\hline$R$-squared & 0.16 & 0.26 \\
\hline
\end{tabular}

Notes: This table presents regressions of the share of immigrants in 1971 in political district $i$, where $i=\{1$, ..., 111\}, on vote shares for the Deutsche Nationalsozialistische Arbeiterpartei, the Austrian counterpart of the German NSDAP, in 1930.

and the recent immigration influx. This ameliorates the concern that historical attitudes may drive contemporaneous settlement patterns. ${ }^{16}$

In sum, we do not find evidence pointing to a significant relationship between pre-existing political preferences (as measured by past election outcomes) and the ensuing change in the immigrant share at the community level. Although this does not eliminate concerns regarding reverse causality, it makes it much less likely that residential sorting of recent immigrant cohorts contaminates our analysis of the role of rising immigrant shares for subsequent electoral support for the FPÖ.

\section{Fixed Effect Estimates}

In this section we present panel fixed effects estimates of the relation between immigration, voting outcomes, and compositional amenities effects of immigration. In Section 5 we provide evidence based on IV estimation methods.

\subsection{Immigration and Far-Right Voting}

The dependent variable is $F P \ddot{O}_{i t}$, the percentage FPÖ votes in community $i$ in election year $t$. The explanatory variable of primary interest is $I M M_{i t}$, the percentage immigrants (over total resident population) in community $i$ at time $t .{ }^{17}$ In all specifications, we include community fixed effects to control for time-invariant unobserved heterogeneity.

16. We note that if it were indeed the case that fewer immigrants selected into communities with stronger historical cultural prejudices, this would bias against finding an effect of immigration on FPÖ voting in the later empirical investigation.

17. In all regressions in this paper, we weight observations by community population size. Standard errors are robust to heteroskedasticity of unknown form and are clustered on the community and census year levels. 
TABLE 4. The effect of the share of immigrants on the share of FPÖ votes: Fixed effect estimation.

\begin{tabular}{|c|c|c|c|}
\hline & $\begin{array}{c}(1) \\
\text { All } \\
\text { immigrants }\end{array}$ & $\begin{array}{c}\text { (2) } \\
\text { Low skilled } \\
\text { immigrants }\end{array}$ & $\begin{array}{l}\text { (3) } \\
\text { High skilled } \\
\text { immigrants }\end{array}$ \\
\hline Share of immigrants & $\begin{array}{l}0.159^{* * *} \\
(0.039) \\
{[0.107]}\end{array}$ & $\begin{array}{l}0.299^{* * *} \\
(0.046) \\
{[0.154]}\end{array}$ & $\begin{array}{c}-0.757^{* * *} \\
(0.111) \\
{[-0.134]}\end{array}$ \\
\hline Community characteristics ${ }^{\mathrm{a}}$ & Yes & Yes & Yes \\
\hline Community fixed effects & Yes & Yes & Yes \\
\hline Year fixed effects & Yes & Yes & Yes \\
\hline Number of observations & 14,598 & 14,598 & 14,598 \\
\hline Mean of dependent variable & 0.156 & 0.156 & 0.156 \\
\hline S.d. of dependent variable & 0.094 & 0.094 & 0.094 \\
\hline Mean share of immigrants & 0.073 & 0.057 & 0.014 \\
\hline S.d. of share of immigrants & 0.063 & 0.048 & 0.017 \\
\hline
\end{tabular}

Notes: This table summarizes the estimated effect of immigration on the share of votes for the FPÖ based on a series of weighted (community population weights) OLS estimations with community fixed effects using Austrian community level data. The dependent variable $\left(F P \ddot{O}_{i t}\right)$ is equal to the share of votes for the FPÖ in the general election in community $i$ in the year $t$, where $t=\{1979,1983,1990,1994,1999,2002,2013\}$. In column (1), the key explanatory variable is the share of residents without Austrian citizenship. Columns (2) and (3) differentiation immigrants by skill levels. The share of immigrants with a certain level of education is equal to the number of residents without Austrian citizenship with the respective educational attainment as a fraction of all residents. Shares by skill are calculated based on residents 25 years of age or older and refer to the highest attained educational degree. Low and medium skills are compulsory schooling, an apprenticeship, or a lower secondary school. High education is a higher secondary school or an academic degree. The shares of immigrants on a community-level are available in the years 1971, 1981, 1991, 2001, 2011 (census years). The share of immigrants in the years 1979 and 1983 is imputed with information form the year 1981, the data in the years 1990 and 1994 are imputed with information form the year 1991, the data in the years 1999 and 2002 are imputed with information from the year 2001, and the data in the year 2013 are imputed with information form the year 2011. The same imputation is used for the other covariates. Robust standard errors (allowing for clustering on the community and census year levels and/or heteroskedasticity of unknown form) are in parentheses. Standardized

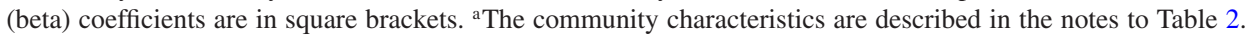
$* * *$ Significant at $1 \%$.

The evidence presented in Table 4 strongly suggests a positive (within community) relationship between immigration and the support for the far right. ${ }^{18}$ These results are based on all national elections in the sample that are at most three years from a census. Some of these elections are before a census and hence the measured covariates may not perfectly capture community characteristics at the election date. To minimize such measurement issues, in analysis on request, we confine the sample to elections after the previous census. It turns out that our results remain unaffected, as point estimates remain essentially unchanged. This is also consistent with the results obtained in

18. The full regression is shown in Table B.1 in Online Appendix B. Although unemployment is univariately positively associated with FPÖ votes, including socioeconomic controls makes this variable insignificant and reverses the sign. The pure OLS estimate (without community fixed effects) for immigration is around 0.1, thus smaller than the fixed effect estimate. 
Section 3 that immigrant sorting does not appear to be driven by election outcomes. We verify in Section 5.3 that when running the OLS regressions with fixed effects as a log-log specification (which corresponds to regressing percent changes in FPÖ vote shares on percent changes in immigrant shares), we obtain quantitatively similar results.

We also checked whether the estimates of the impact of immigration on FPÖ voting are sensitive to the inclusion of additional (or omission of some) controls. For example, Table B.2 in Online Appendix B shows that the estimated effects of immigration on FPÖ votes do not vary strongly when we add educational attainment proxies. ${ }^{19}$

An important question especially in the context of the current situation in Europe is whether there are nonlinearities (or even nonmonotonicities) in the relationship between immigration and far-right voting. On the one hand, it is conceivable that there exist "tipping points" of immigration levels, below which immigration has little effect and above which immigration has dramatic effects. On the other hand, it is possible that beyond a certain level of immigration, the impact of immigration on far-right voting levels of. To examine these possibilities, we consider several different functional forms to model the impact of immigration on FPÖ votes. For example, we add a quadratic term of the immigration share to our model, but this quadratic term does not enter significantly. Alternatively, we run regressions allowing for different slopes at different levels. Results available on request show that the slope of the relationship between immigration and FPÖ voting is essentially homogenous. Specifically, the confidence intervals of the various point estimates at different immigration levels all are such that a common slope of 0.159 , as estimated in column (1) of Table 4, cannot be rejected. We conclude that the simple linear model captures the immigration effect quite well.

Overall, we obtain evidence of a strong association between the share of immigrants and electoral support for the FPÖ within communities, that is, when controlling for unobserved time-invariant heterogeneity. The relationship is quantitatively relevant: A one percentage-point increase in the share of immigrants is associated with a 0.16 percentage-point increase in the FPÖ vote share in that community. This implies that a one standard deviation increase in the local share of immigrants is associated with a 0.11 standard deviation increase in the FPÖ vote share.

19. Although including a large set of controls as in our main specifications clearly has the advantage of mitigating the possibility that an important variable remains omitted, it does have a drawback: Some characteristics of the resident population may themselves be influenced by immigration (for instance, via their participation in the local labor market). We, therefore, also re-estimate our models using a more parsimonious specification (controlling for the community's number of inhabitants, the number of inhabitants squared, the natives' age-sex distribution (22 groups), the natives' distribution of marital status (shares of inhabitants who are single, married, divorced, and widowed)). Table B.2 in Online Appendix B shows that the results continue to hold for this minimal specification. We further confirmed the robustness of our results to the exclusion of observations of larger cities (more than 180,000 inhabitants). 


\subsection{What Drives the Association of Immigration and Far-Right Voting?}

A natural starting point for understanding voting decisions is the hypothesis that rational and self-interested individuals vote for the party that promises them the greatest utility (Downs 1957). We focus on two specific channels through which immigration is likely to affect voter welfare: labor market competition and neighborhood quality.

First, economic theory suggests that immigration hurts natives supplying production factors closely substitutable by those of immigrants. In contrast, individuals who supply complementary factors will gain from immigration. Presenting antiimmigration platforms, far-right parties should appeal to voters who lose from immigration. Specifically, low-skill immigration would be perceived as particularly problematic by Austrian voters. Moreover, we hypothesize that voters in highunemployment communities and in communities with strong labor market competition among natives and immigrants should be more inclined to the far right in response to immigration.

Second, the natives' assessments of the impact of immigration on "compositional amenities" that they derive from their neighborhoods, schools, and workplaces can be an important source of anti-immigration sentiments, as documented in Card et al. (2012) (see also Hainmueller and Hiscox 2010; Dustmann and Fabbri 2003). Education is likely to play a key role. On the one hand, a stronger effect of low-skilled immigration than of high-skilled immigration is also consistent with the compositional amenities argument. On the other hand, we hypothesize that communities with many educated voters (who are likely to worry most about the quality of schooling) and communities with a lot of immigrant children would be more likely to lean to the far right when immigration increases.

4.2.1. Heterogeneous Effects by Immigrant Groups. We first investigate how the education levels of immigrants affect voting decisions of natives. We construct two groups of immigrants according to educational attainment, distinguishing between lowand medium-skilled immigrants on the one hand and high-skilled immigrants on the other hand. Columns (3) and (4) of Table 4 present the results. We find strong evidence that low-skilled immigration is strongly positively associated with far-right voting. By contrast, high-skilled immigration has a negative sign. A one standard deviation increase in the local share of low-skilled (high-skilled) immigrants is associated with a $0.15(0.13)$ standard deviation increase (decrease) in the FPÖ vote share.

We also considered the possible role of cultural and ethnic distance relative to the native population as a driver of anti-immigration voting support. Immigrants from Turkey and ex-Yugoslavia have historically been the most important ethnic groups. They are also among those most often exposed to public verbal attacks by rightwing extremists. Since most Turkish immigrants are Muslims, the effects of Turkish immigrants essentially also capture the role of religion. ${ }^{20}$ Results available on request

20. Evidence from the United Kingdom suggests that Muslims integrate less and more slowly than non-Muslims (Bisin et al. 2008). 
show a somewhat stronger association of these immigrants with FPÖ voting. However, contrary to the results for the role of the education level of immigrants, these differential results later are not supported in the IV estimations.

4.2.2. Heterogeneous Effects across Communities. In this section, we explore which community characteristics interact with immigration to generate political support for the far right. In Table 5, we consider four sample splits along the following community characteristics: (i) unemployment among natives, (ii) labor market competition between immigrants and natives, (iii) ratio of immigrant kids to native kids, and (iv) average educational attainment of natives. ${ }^{21}$

In Panel A, we find that the impact of immigration varies with the level of unemployment of Austrians. In communities where the unemployment rate of Austrians is on the top quartile, the effect of immigration is nearly twice as big than in communities with unemployment in the bottom quartile. In Panel B we consider more directly the intensity of competition between immigrants and Austrians. Following Card (2001), we construct an index of skill overlap among immigrants and natives. ${ }^{22}$ The results imply that the impact of immigration is stronger where immigrants and Austrians are more likely to compete. In results available on request, we compute an alternative index that uses industry information, and we obtain results pointing in the same direction. ${ }^{23}$

Panel C considers the role of the education level of natives. Specifically, we split the sample according to the average educational attainment of natives, based on a four-point scale drawing on the four levels of education described in the data section. The natives' education can be relevant in this context for two reasons. On the one hand, high native education makes it likely that incoming immigrants have relatively lower education. Thus, these immigrants are less likely to compete with the natives

21. Samples are split according to the distribution of the respective variable observed in 1981. Notice that the sample splits themselves may be subject to endogeneity concerns in that, for example, communities in the top 25th percentile in one dimension are likely different also in other dimensions. It is possible that our control variables do not capture all other differences.

22. Specifically, we compute the following index $C$. Let $f_{j}^{A}$ and $f_{j}^{I}$ denote the fractions of Austrians (A) and immigrants $(I)$ with education level $j$. For the calculation of this index, we use all six education levels compulsory schooling, completed apprenticeship training, lower secondary school, higher secondary school, or academic degree separately. Let $f$ denote the fraction of the overall workforce with this education level. Consider an increase in the population of immigrations that generates a 1-percentage-point increase in the total workforce. Assuming that the new immigrants have the same education distribution as the existing immigrants, the percentage increase in the workforce of skill level $j$ is $f_{j}^{I} / f_{j}$. For Austrians, the weighted average increase in the supply of labor to their education-specific labor markets is given by $C_{A, I}=\sum_{j} f_{j}^{A} f_{j}^{I} / f_{j}$, which is the competition index. This index is 1 if Austrians and immigrants in a particular community have the same distribution of education levels. It can be greater than 1 if they have similar education level distributions, and if both Austrians and immigrants are concentrated in a subset of education levels. The index is 0 if Austrians and immigrants have completely different education levels.

23. More than half of all immigrants are employed in construction, trade, hotel and restaurants, and real estate/entrepreneurial services. Although roughly $40 \%$ of Austrians are also employed in these sectors on average, there is wide variation across communities in the importance of these industries. We find that where a larger fraction of Austrians is employed in these industries, the effect of immigration is stronger. 
TABLE 5. The role of labor market concerns and of compositional amenities for the effect of the share of immigrants on the share of FPÖ votes: Fixed effect estimation.

\begin{tabular}{|c|c|c|c|c|c|c|}
\hline Sample split criterion & $\begin{array}{c}(1) \\
\text { Below } \\
\text { 25th } \\
\text { percentile }\end{array}$ & $\begin{array}{c}(2) \\
\text { Below } \\
\text { 50th } \\
\text { percentile }\end{array}$ & $\begin{array}{c}(3) \\
\text { Above } \\
\text { 50th } \\
\text { percentile }\end{array}$ & $\begin{array}{c}(4) \\
\text { Above } \\
75 \text { th } \\
\text { percentile }\end{array}$ & $\begin{array}{l}\text { (5) } \\
t \text {-stati } \\
\text { for the } \\
(1)=(4)\end{array}$ & $\begin{array}{l}\quad(6) \\
\text { tics }^{\mathrm{a}} \\
\text { test of: } \\
(2)=(3)\end{array}$ \\
\hline \multicolumn{7}{|c|}{ Panel A: Unemployment rate of natives } \\
\hline Share of immigrants & $\begin{array}{c}0.115^{* * *} \\
(0.035) \\
{[0.058]}\end{array}$ & $\begin{array}{c}0.149^{* * *} \\
(0.029) \\
{[0.073]}\end{array}$ & $\begin{array}{c}0.167^{* * *} \\
(0.050) \\
{[0.116]}\end{array}$ & $\begin{array}{c}0.253^{* * *} \\
(0.057) \\
{[0.183]}\end{array}$ & $\begin{array}{c}2.080 \\
\{0.038\}\end{array}$ & $\begin{array}{c}0.310 \\
\{0.757\}\end{array}$ \\
\hline $\begin{array}{l}\text { Mean of dep var } \\
\text { Mean of split var }\end{array}$ & $\begin{array}{l}0.148 \\
0.023\end{array}$ & $\begin{array}{l}0.145 \\
0.027\end{array}$ & $\begin{array}{l}0.160 \\
0.058\end{array}$ & $\begin{array}{l}0.162 \\
0.066\end{array}$ & & \\
\hline \multicolumn{7}{|c|}{ Panel B: Labor market competition } \\
\hline Share of immigrants & $\begin{array}{c}0.013 \\
(0.043) \\
{[0.007]}\end{array}$ & $\begin{array}{c}0.047 \\
(0.033) \\
{[0.037]}\end{array}$ & $\begin{array}{c}0.191^{* * *} \\
(0.050) \\
{[0.119]}\end{array}$ & $\begin{array}{c}0.218^{* * *} \\
(0.080) \\
{[0.097]}\end{array}$ & $\begin{array}{c}2.245 \\
\{0.025\}\end{array}$ & $\begin{array}{c}2.393 \\
\{0.017\}\end{array}$ \\
\hline $\begin{array}{l}\text { Mean of dep var } \\
\text { Mean of split var }\end{array}$ & $\begin{array}{l}0.137 \\
0.830\end{array}$ & $\begin{array}{l}0.151 \\
0.939\end{array}$ & $\begin{array}{l}0.158 \\
1.005\end{array}$ & $\begin{array}{l}0.160 \\
1.016\end{array}$ & & \\
\hline \multicolumn{7}{|c|}{ Panel C: Educational attainment of natives } \\
\hline Share of immigrants & $\begin{array}{c}-0.041 \\
(0.045) \\
{[-0.010]}\end{array}$ & $\begin{array}{c}-0.046 \\
(0.035) \\
{[-0.013]}\end{array}$ & $\begin{array}{c}0.211^{* * *} \\
(0.043) \\
{[0.146]}\end{array}$ & $\begin{array}{c}0.267^{* * *} \\
(0.051) \\
{[0.190]}\end{array}$ & $\begin{array}{c}4.517 \\
\{0.001\}\end{array}$ & $\begin{array}{c}4.620 \\
\{0.001\}\end{array}$ \\
\hline $\begin{array}{l}\text { Mean of dep var } \\
\text { Mean of split var }\end{array}$ & $\begin{array}{l}0.139 \\
1.481\end{array}$ & $\begin{array}{l}0.144 \\
1.544\end{array}$ & $\begin{array}{l}0.159 \\
1.878\end{array}$ & $\begin{array}{l}0.159 \\
1.932\end{array}$ & & \\
\hline \multicolumn{7}{|c|}{ Panel D: Ratio of immigrant kids to all kids } \\
\hline Share of immigrants & & $\begin{array}{c}-0.045 \\
(0.044) \\
{[-0.010]}\end{array}$ & $\begin{array}{c}0.207^{* * *} \\
(0.042) \\
{[0.142]}\end{array}$ & $\begin{array}{c}0.258^{* * *} \\
(0.046) \\
{[0.177]}\end{array}$ & $\begin{array}{l}4.788^{\mathrm{b}} \\
\{0.001\}\end{array}$ & $\begin{array}{c}4.176 \\
\{0.001\}\end{array}$ \\
\hline Mean of dep var & & 0.143 & 0.159 & 0.160 & & \\
\hline Mean of split var & & 0.019 & 0.101 & 0.121 & & \\
\hline
\end{tabular}

Notes: This table summarizes the estimated effect of immigration on the share of votes for the FPÖ based on a series of weighted (community population weights) OLS estimations with community fixed effects using Austrian community level data. The regressions are equivalent to those presented in Table 4, but are estimated for different subsamples. In each panel, the split variable is stated at the header. The columns (1)-(4) indicate sample splits at the first quartile, the median, and the third quartile of the split variable stated at the header of each column. Splits are conducted according to the distribution of the respective variable observed in 1981 . The construction of the labor market competition index (Panel B) follows Card (2001) and is explained in detail in the text. Average educational attainment of natives (Panel C) is based on a four-point scale, drawing on the four levels of education described in the data section. The calculation of immigrant shares is described in the notes to Table 4 . All regressions include the same set of controls as the estimations summarized in Table 4. Robust standard errors (allowing for clustering on the community and census year levels and/or heteroskedasticity of unknown form) are in parentheses. Standardized (beta) coefficients are in square brackets. ${ }^{a}$ Column (5) provides the $t$-statistics and $p$-values in curly brackets for the hypothesis that the coefficients of interest in the subsamples from columns (1) and (4) are identical. Column (6) provides the $t$-statistics and $p$-values in curly brackets for the hypothesis that the coefficients of interest in the subsamples from columns (2) and (3) are identical. All $t$-statistics are based on fully interacted models using the respective pooled samples and report the $t$-statistic on the coefficient of the interaction term between the share of immigrants and a binary indicator for the second sample. ${ }^{\mathrm{b}}$ In the case of Panel D, columns (2) and (4) are compared. ***Significant at $1 \%$. 
on the labor market. Well-educated natives would, therefore, benefit from low-skilled immigration. We would then expect the impact of immigration on FPÖ voting to be less pronounced where Austrians are highly educated. On the other hand, high-skilled natives may particularly worry about the quality of schools and other compositional amenities. The results in Panel $\mathrm{C}$ suggest that the latter effect dominates. Another reason for the result of Panel $\mathrm{C}$ could be that in communities with more high-skilled natives, political polarization may be stronger, generating stronger FPÖ support among the potential losers.

Finally, Panel D documents that proximity of immigrants is especially strongly related to far-right voting where there are many immigrant children compared to Austrian children, indicating that Austrians worry about the quality and cultural composition of their schools. ${ }^{24}$

\subsection{The Effect of Immigration on Outcomes that Might Affect Voting Behavior}

The above findings are consistent with the labor-market competition channel. They are also consistent with the idea that Austrians worry about compositional amenities. Although voting does not have to be fully rational, rationality would have a stronger claim to explaining the results if immigration in fact worsens labor market opportunities for natives or reduces the quality of schooling or the quality of other amenities. Also, we study whether natives respond only through voting decisions, or whether they also use the exit option, migration.

Labor Market Effects. A large (and controversial) literature discusses the actual labor market effects of immigration. Some studies (for example, Borjas 2003) find strong negative effects on native wages, whereas others do not find strong effects (e.g., Card 2005, 2009). ${ }^{25}$

There are a few studies analyzing the labor market implications of immigration on the native population in Austria. Winter-Ebmer and Zweimüller (1996) and WinterEbmer and Zweimüller (1999) find no significant effects on earnings and employment following the immigration wave of the early 1990s on young Austrian natives. The result of these early studies has been confirmed more recently by Bock-Schappelwein et al. (2008) who find no statistically significant impact of immigration on natives in micro wage regressions; and Horvath (2011) who finds that increases in immigration had no significant impact on the lower part of the native wage distribution but a slightly positive and statistically significant impact on the top of the distribution. In sum, the available Austrian evidence does not strongly support the idea that native wages are strongly affected by immigration. However, the evidence is scarce and even if it precisely measures the true effect of immigration on the labor market, it is perceived

24. In the case of this sample split, a separate calculation below the 25 th percentile is not feasible, because in the year 1981 more than $25 \%$ of the communities had no underage immigrants.

25. The impact of immigration on the size of the consumer base plays a critical role, complicating theoretical predictions of labor-market effects (Borjas 2009). 
rather than actual threat by immigrants that matters for voting behavior of natives. European and World Values Survey based evidence indeed suggests that Austrians perceive immigrants as a threat for their labor market opportunities (see Table C.3 in Online Appendix C).

Effects on Compositional Amenities. Voting for the far right may be driven by the impact of immigration by affecting the quality of the local neighborhoods (schools, workplaces, residential areas, etc.). For instance, Speciale (2012) shows that public education expenditures in EU-15 countries are lower the higher the influx of immigrants. In order to shed light on this potentially important channel, we consider several proxies for compositional amenities and measure whether they respond to an increase in local immigration. ${ }^{26}$

First, we consider schooling quality in a community. School quality for native children may either be lower due to less funding in high-immigration communities or due to the mere fact that a large fraction classmates with immigration families who are not fluent in German, may have a detrimental effect for native children due to a lower quality of teaching. There are no direct measures available in Austria. In particular, a standardized high school test was only introduced in 2014/2015. Therefore, we construct a proxy. Specifically, we measure the fraction of school children that are commuting more than 15 minutes to school, which very often means that they commute to another community. This information is provided in the census until 2001. Such out-commuting reflects the combination of two factors, both of which indicate lower schooling quality in the home community: first, there may not be a high school or gymnasium in a community; second, there may be a school, but with many immigrant children. For this variable, data are not available for 2011. One average about $40 \%$ of school children out-commute, and this number is slightly decreasing over the years. Columns (1) and (2) of Table 6 show that a one standard deviation increase in the local share of immigrants is associated with a $0.10-0.14$ standard deviation increase in the share of children who out-commute, consistent with the idea that natives worry that immigration may cause disamenities through lower school quality.

Second, we consider to whether immigration affects the probability that a community has one of the following two (public or publicly supported) child-care facilities available: a day-care for children of up to age 3 ("Kinderkrippe") or afterschool child care for school children at ages 6+ ("Hort"). ${ }^{27}$ Data on the existence of these facilities are available from 1991 onward. The provision of these facilities has

26. An important literature-which we do not discuss here—considers whether and to which extent immigration causes crime. This large and increasing literature did so far not generate conclusive evidence, with some studies finding positive, and other studies finding insignificant effects. However, it seems that the fear of becoming a crime victim is associated with immigration. See, for example, Bianchi, Buonanno, and Pinotti (2012) for a discussion of the recent literature. Although we think crime (or fear of crime) may be an important mechanism that drives voting in response to immigration, lack of appropriate regional data does not allow us to study this in this paper.

27. In most Austrian schools, teaching ends at noon or 2 p.m. Day care for kids aged 3-6 (Kindergarten) is available in almost all communities. 


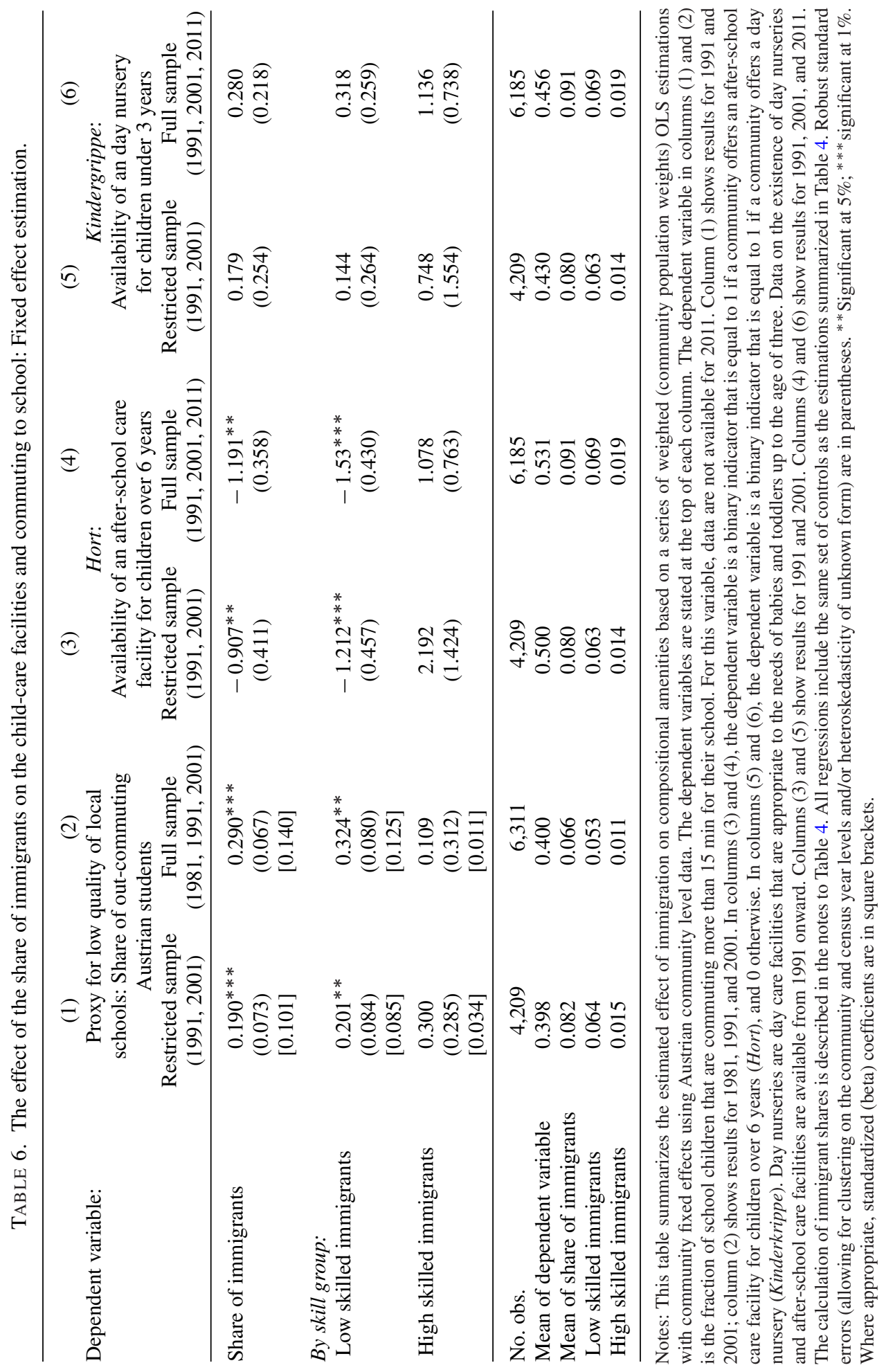


been increasing. For example, although in 1991, $40.5 \%$ of the population had access to a day nursery in their community, that share had increase to $51 \%$ in 2011 . Similarly, although in 1991, there were afternoon care centers in the community for $47 \%$ of the population, in $2011,59 \%$ of the population had access to such a facility.

We are primarily interested in whether there are differential trends in public childcare provision between high- and low-immigration communities. The hypothesis is that policy makers may be more strongly focused on the voting population and hence may allocate fewer funds to communities with a stronger increase in immigration. Consequently, the availability of childcare facilities may grow less in high-immigration communities. Columns (3) and (4) provide evidence supporting this hypothesis for after-school care ("Hort"). A one percentage point increase in the local share of immigrants is associated with a $0.9-1.2$ percentage point decrease in the probability that after-school care is available in a community. ${ }^{28}$ For day nurseries ("Kinderkrippen"), we find no significant result.

Overall, our results support the idea that high-immigration communities did benefit to a lesser extent from (the growth of) local amenities related to care for school- and preschool children. This lower extent of child-related amenities may create worries for insufficient child-support children by native parents for their own children. This, in turn, could induce them to find anti-immigrant slogans attractive and to support anti-immigration policies by voting for the FPÖ.

Native Migration. Austrians may respond in various ways if increased immigration makes them increasingly dissatisfied with the quality of their neighborhoods. In particular, they may vote for an anti-immigration party ("voice"), or they may move away ("exit"). Although this paper focuses on the voting reaction, the native migration patterns are of interest: If Austrians who worry about immigrants were to move away, the overall impact of immigration on far-right support will be understated by our analysis. The reason is that voters whose welfare is negatively affected by the proximity of immigrants (and who would, therefore, more readily gravitate to the FPÖ) who are more likely to have moved elsewhere, thus weakening the relationship between immigration and FPÖ support observed at the community level.

To test for the importance of native internal migration responses, we follow Peri and Sparber (2011). The question is how many natives $(N)$ respond to the arrival of immigrants $(I)$ by leaving their place of residence $i$. To estimate the quantitative importance of such migration responses, the following model is estimated: $\Delta N_{i, t}=\alpha+\beta \cdot \Delta I_{i, t}+u_{i, t}$ with $\beta$ being the interesting parameter. Various scholars have proposed different versions of this model, mainly considering different measurement concepts of dependent and independent variables. We use the slightly

28. It is possible that immigrants are more likely than natives to provide afternoon care themselves, and so less such services need to be provided externally. We do not have data to examine this conjecture directly. Our dependent variable in this analysis is whether there is after-school care available, not how many places there are in a given facility. 
TABLE 7. Estimation of the internal migration response to a change in share of immigrants by skill-levels of natives and immigrants.

\begin{tabular}{|c|c|c|c|c|}
\hline Dependent variable: & $\begin{array}{c}(1) \\
\text { Change in } \\
\text { share of } \\
\text { natives }\end{array}$ & $\begin{array}{c}(2) \\
\text { Change in } \\
\text { share of } \\
\text { natives }\end{array}$ & $\begin{array}{c}(3) \\
\text { Change in } \\
\text { share of high } \\
\text { skilled natives }\end{array}$ & $\begin{array}{c}\text { (4) } \\
\text { Change in } \\
\text { share of low } \\
\text { skilled natives }\end{array}$ \\
\hline Change in share of immigrants & $\begin{array}{c}0.024 \\
(0.034) \\
{[0.008]}\end{array}$ & & & \\
\hline \multicolumn{5}{|l|}{ By skill group: } \\
\hline $\begin{array}{l}\text { Change in share of low skilled } \\
\text { immigrants }\end{array}$ & & $\begin{array}{c}0.009 \\
(0.047) \\
{[0.003]}\end{array}$ & $\begin{array}{c}0.013 \\
(0.019) \\
{[0.012]}\end{array}$ & $\begin{array}{c}-0.027 \\
(0.046) \\
{[-0.011]}\end{array}$ \\
\hline $\begin{array}{l}\text { Change in share of high skilled } \\
\text { immigrants }\end{array}$ & & $\begin{array}{c}0.558 * * * \\
(0.150) \\
{[0.189]}\end{array}$ & $\begin{array}{c}0.365^{* * *} \\
(0.073) \\
{[0.343]}\end{array}$ & $\begin{array}{c}0.298^{* *} \\
(0.130) \\
{[0.119]}\end{array}$ \\
\hline No. obs. & 6,832 & 6,832 & 6,832 & 6,832 \\
\hline Mean of dependent variable & 0.020 & 0.020 & 0.045 & -0.023 \\
\hline S.d. of dependent variable & 0.080 & 0.080 & 0.029 & 0.068 \\
\hline $\begin{array}{l}\text { Mean of change in share of } \\
\text { immigrants }\end{array}$ & 0.015 & & & \\
\hline $\begin{array}{l}\text { Mean of change in share of low } \\
\text { skilled immigrants }\end{array}$ & & 0.011 & 0.011 & 0.011 \\
\hline $\begin{array}{l}\text { Mean of change in share of high } \\
\text { skilled immigrants }\end{array}$ & & 0.004 & 0.004 & 0.004 \\
\hline
\end{tabular}

This table summarizes estimation output of empirical models for identifying the internal migration response as discussed and evaluated by Peri and Sparber (2011) (henceforth PS). The estimations are based on Austrian community-level panel data for the years 1981, 1991, 2001, and 2011. The dependent variable in columns (1) and (2) is defined as $\left(N_{t}-N_{t-1}\right) /\left(N_{t-1}+I_{t-1}\right)$, where $N$ denotes the absolute number of natives, and $I$ the absolute number of immigrants residing in the respective community in period $t$. The dependent variable in column (3) is defined as $\left(N_{t}^{\text {high }}-N_{t-1}^{\text {high }}\right) /\left(N_{t-1}\right)$, where $N^{\text {high }}$ denotes the absolute number of high-skilled natives. The dependent variable in column (4) is defined as $\left(N_{t}^{\text {low }}-N_{t-1}^{\text {low }}\right) /\left(N_{t-1}\right)$, where $N^{\text {low }}$ denotes the absolute number of low-skilled natives. The explanatory variable in column (1) is defined as $\left(I_{t}-I_{t-1}\right) /\left(N_{t-1}+I_{t-1}\right)$. The first explanatory variable in column (2) to (4) is defined as $\left(I_{t}^{\text {low }}-I_{t-1}^{\text {low }}\right) /\left(N_{t-1}+I_{t-1}\right)$, where $I^{\text {low }}$ denotes the absolute number of high-skilled immigrants. The second explanatory variable in columns (2)-(4) is defined as $\left(I_{t}^{\text {high }}-I_{t-1}^{\text {high }}\right) /\left(N_{t-1}+I_{t-1}\right)$, where $I^{\text {high }}$ denotes the absolute number of high-skilled immigrants. Low skills is compulsory schooling, an apprenticeship, or a lower secondary school. High education is a higher secondary school or an academic degree. Each specification controls for community and year fixed effects. This specification is analogous to the preferred specification of PS - a slightly modified specification of Card (2001, 2007) which they describe/recommend on page 90. A statistically significant negative (positive) coefficient indicates displacement (attraction) of natives. Robust standard errors (allowing for clustering on the community level) are in parentheses. ${ }^{* *}$ Significant at $5 \% ;{ }^{* *}$ significant at $1 \%$. Standardized (beta) coefficients are in square brackets.

modified specification of Card (2001, 2007), which is the preferred specification of Peri and Sparber (2011).

Table 7 summarizes the estimation output of three empirical models for our community-level panel data. Column (1) shows that, overall, there is no evidence of a strong internal migration response of Austrians. This evidence is in line with the 
common stereotype that the Austrian population is not very mobile. Frictions in the housing market may also make internal migration difficult.

Turning to skill groups (columns (2)-(4)), it is interesting to note that we do not find evidence of Austrians moving away from (or into) communities with substantial low-skilled immigration. This suggests that the impact of low-skilled immigration on voting outcomes is primarily due to changing preferences of existing voters, not due to a changing composition of the electorate. However, we obtain some suggestive evidence that for Austrians, moving into communities with recent inflows of highskilled immigration is attractive. As long as these movers do not support the FPÖ, this finding can partly explain why high-skilled immigration is associated with less FPÖ voting.

\section{Instrumental Variables}

In this section we propose an instrumental variable (IV) strategy for identifying the effects of immigration on FPÖ votes. This is of interest because even a fixed effect regression does not necessarily identify the causal effect of local immigration on local FPÖ votes due to time-varying unobserved heterogeneity. Specifically, a concern is that a community may be hit by a negative economic shock that depresses housing prices, making it more affordable for immigrants to settle there. At the same time, this shock may incline voters to the far right. Although we control for a rich and time-varying set of economic and demographic variables, as well as the industry structure, it is not possible to rule out this concern in the fixed-effect setting.

Our identification strategy relies on historical settlement patterns (see Altonji and Card 1991), an instrument that is frequently used in immigration studies. It turns out that this instrument works in many (though not in all) of our regressions. Particularly when we look at certain subgroups, the first stage runs into statistical problems. Overall, the results of this section provide an important complement to our fixed effect results.

\subsection{Background and IV Strategy}

Historical settlement into Austria is characterized by a sudden, large inflow of immigrants in the 1960s. Until the early 1960s very few non-Austrians lived in Austria (except a base stock of Germans whose overall size remained essentially unchanged for the following 30 years). However, in the 1950s and 1960s, the post-War boom of the Austrian economy led to a growing demand for labor amid increasing labor shortages. In the 1960s, the Austrian government began to forge bilateral agreements with southern and southeastern European states to recruit temporary workers. A 1964 agreement with Turkey and a 1966 agreement with Yugoslavia attracted Turkish and Yugoslavian "guest workers" into the country. Recruitment offices in those countries were established, and a substantial influx of Turkish and Yugoslavian workers to Austria began. Some raw numbers illustrate the significance of this new regime. In 1961, residents with Turkish and Yugoslavian citizenship numbered 271 and 4,565, 
respectively. By 1971, the numbers had risen 60 -fold and 20 -fold to 16,423 and 93,337, respectively. These guest workers were supposed to stay, by way of rotation, only for a short period of time to cover specific demand for labor. However, they usually wanted to stay longer, and Austrian employers wanted to avoid the cost of labor fluctuations. Thus, in effect, most of the guest workers remained in Austria permanently.

Archival information provides interesting insights into how allocations of guest workers were made in the 1960s. Specifically, the actual number of guest workers in a given community arises out of a combination of two factors: First, the maximum number of guest workers a specific industry in a given region was allocated (the quota); and second, the usage of that quota. The quota was the outcome of regional and industry-specific negotiations between representatives of the Austrian Economic Chambers and the trade unions. The Austrian Institute of Economic Research (Wirtschaftsforschungsinstitut, WIFO) provides an analysis of how this worked for the year 1963 (WIFO 1963). They find that there does not appear to be a clear pattern in the extent to which quotas were set and used. They note that this may have to do with the institutional peculiarities of the various labor markets and that "subjective factors such as negotiation skills" apparently played a role (p. 413, translation by the authors). Moreover, studying the relationship between industry structure and immigrant quotas, they conclude that "the quota size was apparently only partially determined based on labor market data. Quotas are neither positively related to the percentage of vacancies, nor are they negatively related with the unemployment rate" (p. 413). As regards unemployment in 1961, the WIFO analysis (based on regional data) suggests that quotas for immigrants were higher for regions where unemployment was low. To be on the safe side, we do control for the historical unemployment rate in our analysis.

Naturally, immediate family members later joined the predominantly male guest workers. However, in the following decades (e.g., during the Yugoslavian political crisis in 1990 and the war in 1992) a massive influx beyond immediate family members took place. A large literature has established that immigrants settle where they find existing social networks and neighbors with the same cultural and linguistic background (Bartel 1989; Åslund 2005; Jaeger 2007). Therefore, we expect that immigrants today are highly likely located in areas where the first wave of guest workers settled down in the 1960s. ${ }^{29}$

Following Card (2001), therefore, we use the spatial distribution of immigrants in the census-year 1971—which reflects the settlement patterns of the first wave of guest workers - to decompose the actual stock/inflow of immigrants into an exogenous socalled supply-push component and into a residual component reflecting any departures from the historical pattern. Put differently, the idea is to exploit the differential location choices of immigrants from different countries in the 1960s to predict the settlement decisions of immigrants from the same country at later points in time. This predicted

29. Empirical papers show that such networks facilitate the job search and assimilation into the new cultural environment (Munshi 2003). For the importance of networks in general, see Calvó-Armengol and Jackson (2004), Ioannides and Loury (2004), Lazear (1999), and Montgomery (1991). 
share of immigrants should be free from local contemporary demand factors and as such serve as a valid source of exogenous variation.

Importantly, to ameliorate endogeneity concerns even further, we adopt a regression-in-changes approach. In other words, rather than exploiting the crosssectional variation in levels of FPÖ votes and immigrant shares, we exploit the crosssectional variation in changes in FPÖ votes and immigrant shares. This is the natural counterpart to the panel regressions with community fixed effects. ${ }^{30}$

\subsection{Empirical Implementation}

Formally, we wish to explain the change in FPÖ vote share in community $i$ from $t_{1}$ to $t_{2}$ by the change in the immigrant share in the same time period. As we show below, when using percentage point changes for both immigrant shares and FPÖ vote shares, the first stage is, once one includes our main control variables, unfortunately too weak to allow for reliable inference. With percent changes in immigrant shares, we obtain a much stronger first stage and, therefore, more reliable inferences. Therefore, we also use percent changes in FPÖ vote shares as the dependent variable. ${ }^{31}$ In what follows, for simplicity we present the regression setup using this main specification.

In particular, we instrument the percent change in immigration since any given base year $t_{1}$ by the percent change in the predicted share of immigrants from $t_{1}$ to $t_{2}$. Using " $g$ " to highlight "growth" variables, the first-stage regression then is

$$
g I M M_{i t_{2} t_{1}}=a+b \times g I V_{i t_{2} t_{1}}+X_{i t_{1}}^{\prime} \Gamma^{1}+d \times I M M_{i 1971}+\theta_{t}^{1}+\varepsilon_{i t}^{1},
$$

where $g I M M_{i t}$ denotes the percent change in the immigrant share in community $i$ from $t_{1}$ to $t_{2}, X_{i t_{1}}$ is a vector of standard controls, $\theta_{t}^{1}$ is a full set of year dummies, and $\varepsilon_{i t}^{1}$ is a stochastic error term.

The instrumental variable, the percent change in the predicted share of immigrants, is

$$
g I V_{i t_{2} t_{1}}=\frac{\left(\sum_{c} S_{c i}+M_{c t_{2}} \cdot \lambda_{c i}\right) / P_{i t_{2}}-\left(\sum_{c} S_{c i}+M_{c t_{1}} \cdot \lambda_{c i}\right) / P_{i t_{1}}}{\left(\sum_{c} S_{c i}+M_{c t_{1}} \cdot \lambda_{c i}\right) / P_{i t_{1}}} .
$$

30. In specific circumstances, related to policies regarding refugees, researchers can arguably get even closer to random assignment and internal validity than we can in our setting (see, e.g., Edin, Fredriksson, and Åslund 2003; Damm 2009; Glitz 2012; Dahlberg, Edmark, and Lundqvist 2012). Strict exogeneity is not definitely guaranteed even in these settings. In reality, authorities consider at least the location of family members or ethnic clusters. Also, in Austria, for example, communities may deny to provide (or to find) housing for assigned refugees. Moreover, these cases represent a quantitatively less important phenomenon, and it may be more difficult to generalize findings from the refugee assignment approach to a situation where economic migrants decide independently where to settle.

31. Naturally, when there are zero immigrants in a community or zero FPÖ voters, a percent change cannot be calculated. In the few cases where this occurs, we impute one immigrant or one vote. Excluding these observations provides virtually identical results. We also verify that the prior panel fixed effect results are virtually identical on this slightly restricted sample. 
Here $S_{c i}$ is the number of immigrants from source country $c$ residing in community $i$ in the year 1971, $M_{c t}$ is the number of immigrants from source country $c$ who enter Austria between 1971 and $t_{j}, \lambda_{c i}$ is the fraction of immigrants from the pre-1971 cohort of immigrants from source country $c$ who resided in community $i$ in 1971, and $P_{i t_{j}}$ is the total population (i.e., immigrants plus natives) in community $i$ in the year $t_{j}$. The country groups $c$ are: immigrants from ex-Yugoslavia, Turkey, and others. We thus calculate time-varying instruments for various combinations of $t_{1}=1981,1991,2001$ and $t_{2}=1991,2001,2011$ and assign them to election years per the timing convention described in Section 2. The results are very similar if we do not include $S_{c i}$ in the construction of the instrumental variable.

The second-stage regression then is

$$
g F P \ddot{O}_{i t_{2} t_{1}}=\alpha+\beta \times \widehat{g I M M}_{i t_{2} t_{1}}+\mathrm{X}_{i t_{1}}^{\prime} \Gamma^{2}+\delta \times I M M_{i 1971}+\theta_{t}^{2}+\varepsilon_{i t}^{2} \text {, }
$$

where $g F P \ddot{O}_{i t_{2} t_{1}}$ is the percent change of FPÖ votes in community $i t_{1}$ to $t_{2}$; and $\widehat{\operatorname{gIMM}}_{i t_{2} t_{1}}$ is the predicted percent change in immigration from the first-stage regression (1). Moreover, $\theta_{t}^{2}$ is a set of year fixed effects, and $\varepsilon_{i t}^{2}$ is the error term.

The coefficient of interest is $\beta$, which captures the effect of the change in the local presence of immigrants (attracted by existing networks established by guest workers prior to 1971) on the change in FPÖ voting. Specifically, $\beta$ measures the percent change in FPÖ votes that is associated with a $1 \%$ increase in the immigrant share in a community. As in the OLS case, we weight observations by community population size. Standard errors are robust to heteroskedasticity of unknown form, and in the case of panel regressions clustered on the community and census year levels.

When our interest is in the effect of immigration of a specific skill-group, we construct an analogous instrument, using the initial skill-level distribution instead of the initial source country distribution for predicting the allocation of a given inflow of immigrants to communities.

We have shown earlier that Austrian voters do not appear to internally migrate in response to immigration. Moreover, there does not seem to be a relationship between historical Nazi-voting and immigration patterns in 1971. As in the previous panel regressions, we control for a range of controls, including the historical (preimmigrant inflow) industry structure and unemployment rates. ${ }^{32}$ In addition to the covariates used in the previous section, we also control for the immigrant share in 1971 (though the results do not depend on including this variable). Note that the immigrant share in 1971 is included as a control in both stages. In other words, if suffices to assume that the

32. In fact, our results do not depend on controlling on these historical variables. Consistent with this observation, unreported results show no significant relation between our instrumental variable and the unemployment rate in the year 1961. Also, because contemporaneous unemployment itself is highly positively correlated with FPÖ vote shares, omitting the control for labor market status would, if anything, tend to introduce a downward bias into our second-stage estimates. Nonetheless, we control for the whole contemporaneous labor market distribution. 
initial distribution $\lambda_{g i}$ of immigrant groups (but not the levels $S_{g i}$ ) and the subsequent overall inflows to Austria are exogenous.

\subsection{Results}

First-Stage Results. The geographic distribution of immigrants by census year is depicted in Figure 3. Visual inspection strongly suggests that the share of immigrants in later years is higher in communities with a high immigrant share back in 1971. This also translates into a strong relation between predicted and actual shares of immigrants, as demonstrated in the top row of Figure 4. Notice, however, that our IV approach relies on changes. The middle row of Figure 4 shows a positive correlation between the predicted percentage point change in immigrant shares and actually observed percentage point changes in the immigrant share, for various relevant time horizons. However, when including control variables, the first stage in percentage point changes is too weak, yielding $F$-statistics ${ }^{33}$ of only 0.3 to 4 , as can be seen in the lower panel of Table 8 in columns (3), (5), and (7).

Therefore, we consider percent changes. The bottom row of Figure 4 shows that a positive correlation between the instrument, the predicted percent change in immigrant shares, and actually observed percent changes in the immigrant share exists. In this case, the first stage is strong, as can be seen at the bottom of Table 8 in columns (4), (6), and (8) in the high $F$-statistics on the excluded instrument, at least in the 15-20 year differences and the 20+ year differences. The Kleibergen-Paap statistics in our analysis are between 10 and 35. An increase in the predicted share by $1 \%$ is associated with a $0.9 \%-1 \%$ higher actual immigrant share. Results vary only slightly by the corresponding time horizon ( $<15$ years, $>20$ years). ${ }^{34}$ Our main inferences in the IV setting are, therefore, based on the specification in percent changes.

Second-Stage: Main Results. The upper panel of Table 8 presents the main secondstage results for three different time horizons over which changes in the immigrant

33. We report Wald $F$-statistics based on the Kleibergen-Paap $r k$ statistic. The Cragg-Donald $F$-statistic is a basic reference point in 2SLS-regressions; Stock, Wright, and Yogo (2002) provide critical values for strong instruments ( 8.96 in the case of one instrument). However, this statistic requires an assumption of i.i.d. errors. In the presence of clustering and heteroskedasticity, the Kleibergen-Paap $r k$ statistic is, therefore, typically considered additionally in practice. No study appears to exist that provides threshold values that the $r k$ statistic should exceed for weak identification not to be considered a problem, but researchers usually use a value of 10 as an indication of a strong instrument in this case, following the general proposal of Staiger and Stock (1997) for a threshold for the first-stage $F$-statistic. The cutoff values do not provide a mechanical rule.

34. Results available on request show that these effects also hold in a quantitatively very similar form for individual differences (e.g., going from 1981 to 2001, from 1991 to 2001, etc.). There is only one exception: for changes over the period 2001-2011, the coefficient falls to 0.31 , suggesting that inflows in that decade may have become less determined by prior settlement patterns in recent years. However, even then the effect is highly statistically significant, ensuring a strong first stage even in most recent years. 

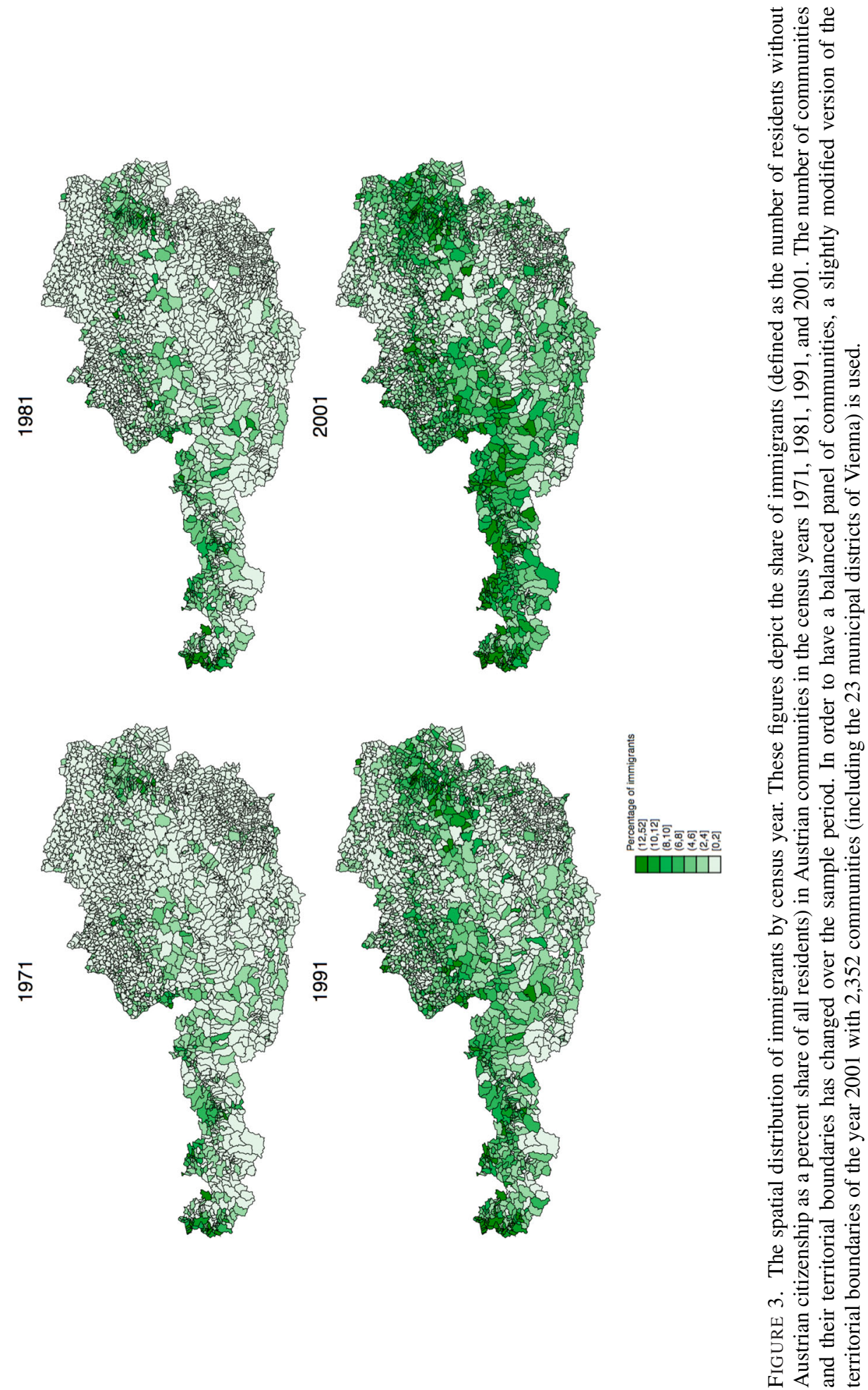

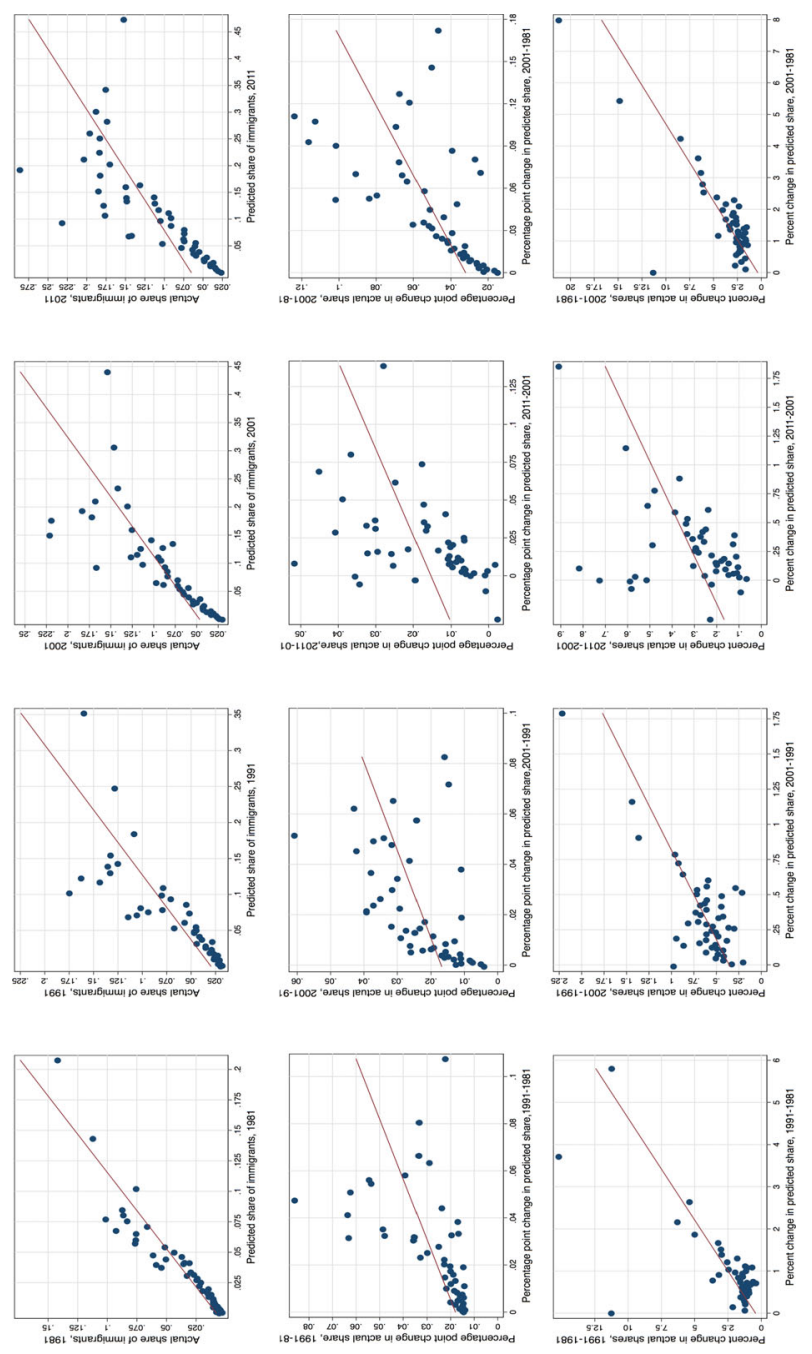

章 总

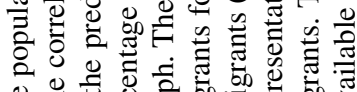

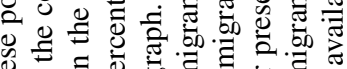

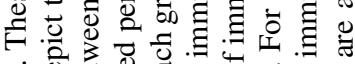

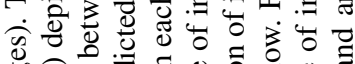

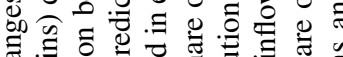

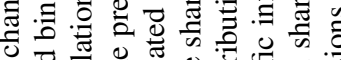

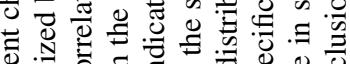

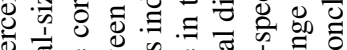

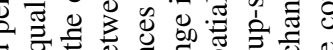
ज्ञ sin of o

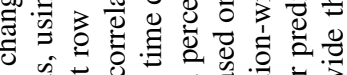

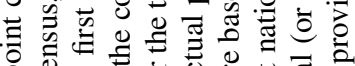
¿

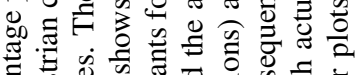

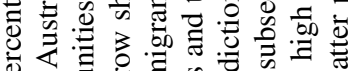

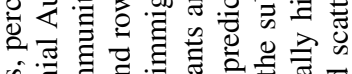

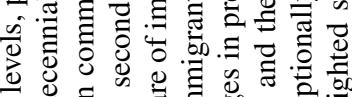
屯.

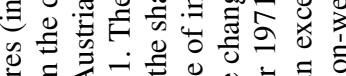

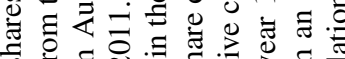

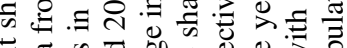

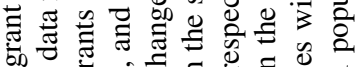

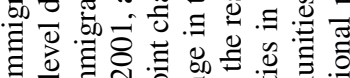

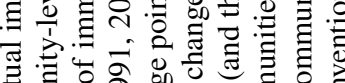

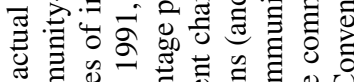

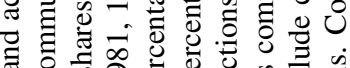
击

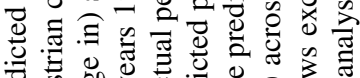

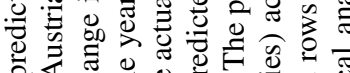

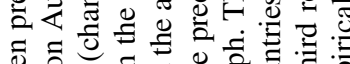
ญี

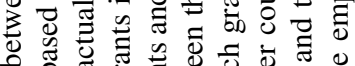
ป ¿

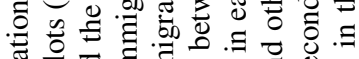

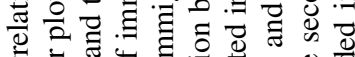

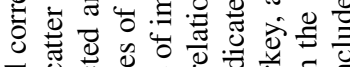
ส

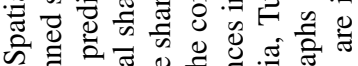

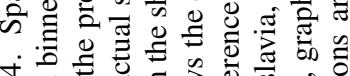

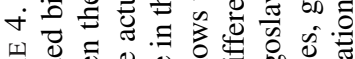

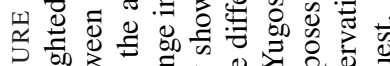

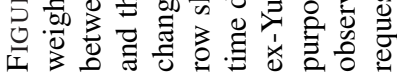




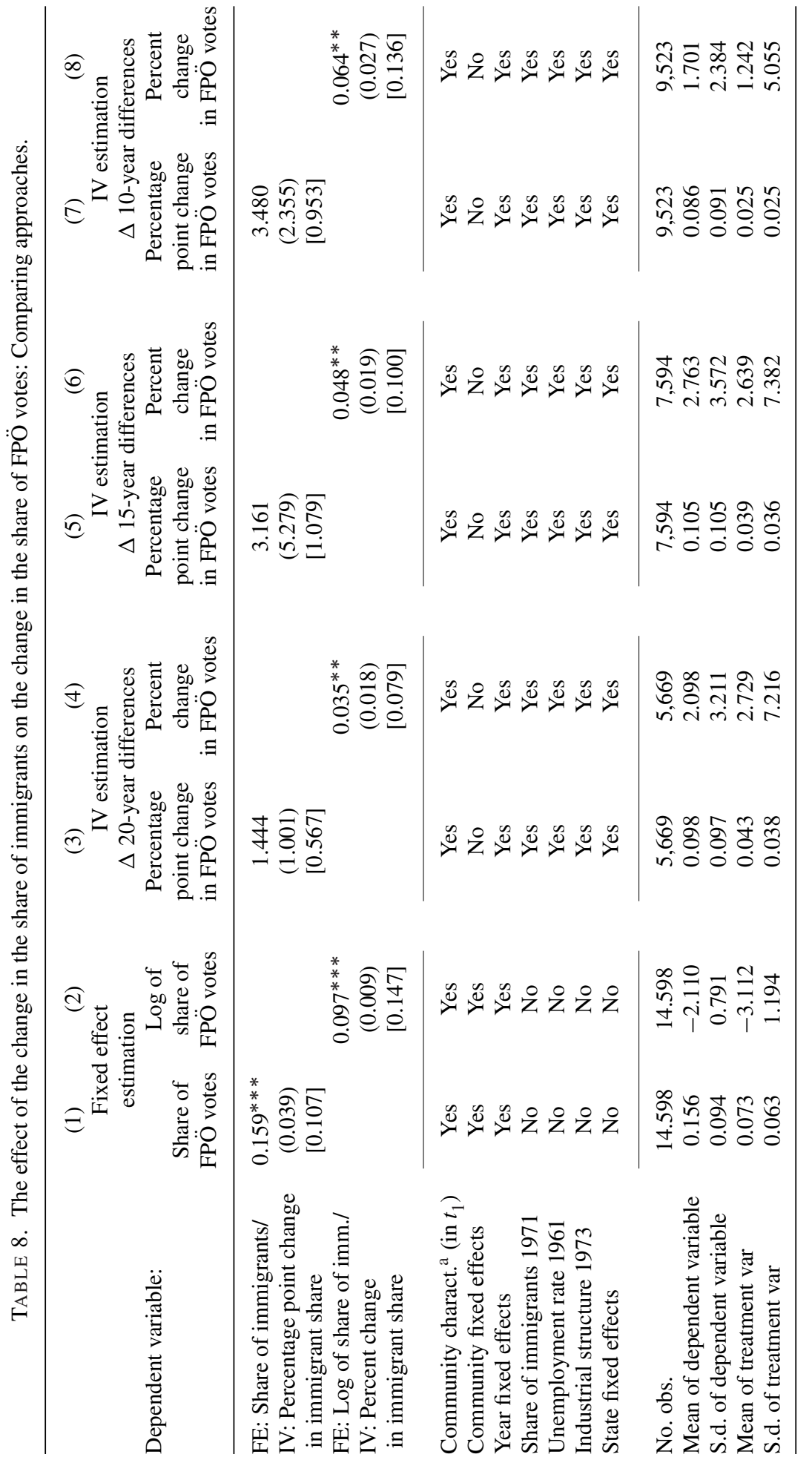




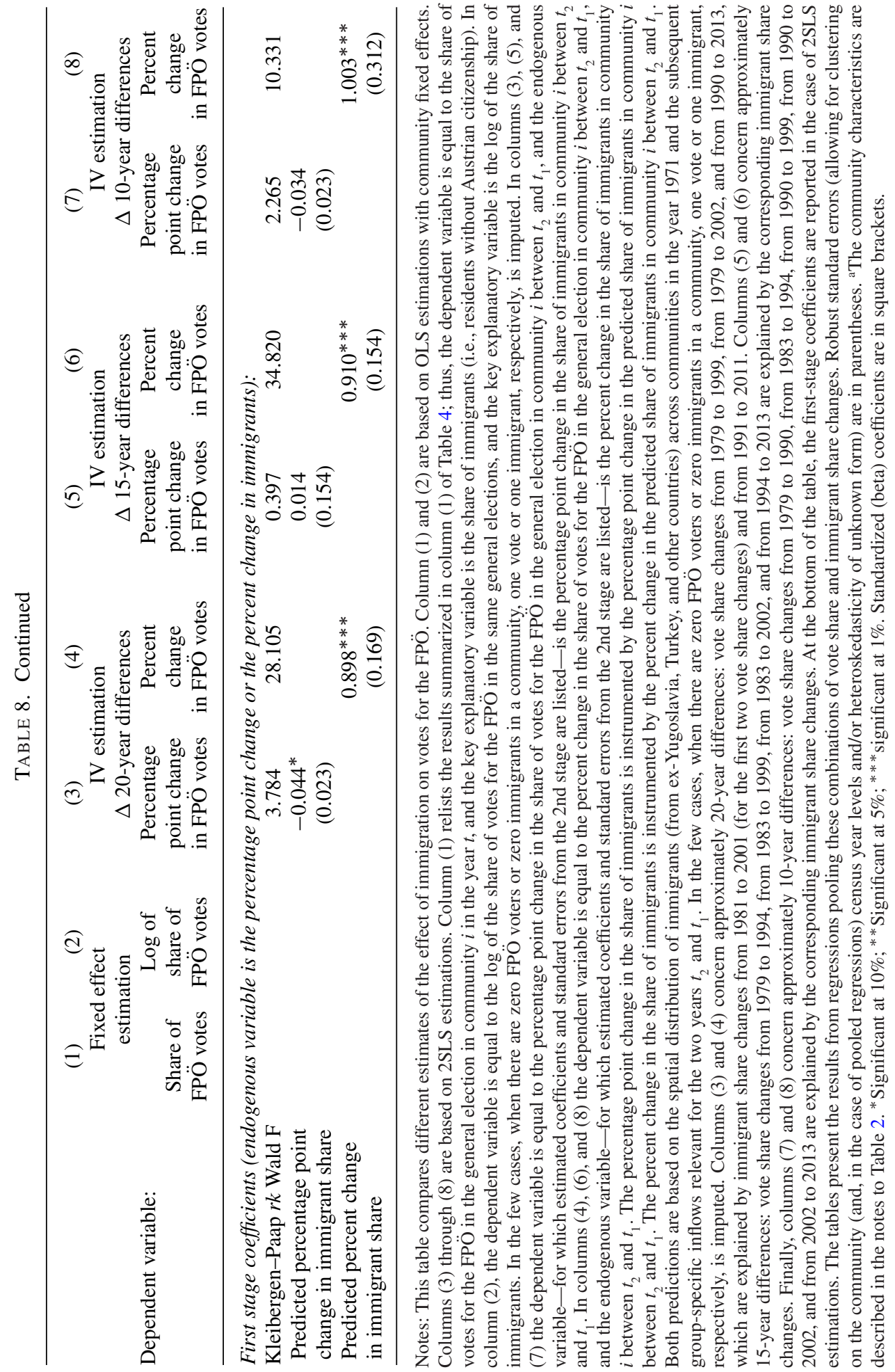


share can be measured (around 10 years, 15 years, and 20 years, respectively). The regressions are based on pooled samples. For instance, in the 20-year difference regression we pool vote share changes from 1979 to 1999 , from 1979 to 2002, and from 1990 to 2013 (and their corresponding first-stage regressions for immigrant share changes from 1981 to 2001 and from 1991 to 2011). We proceed similarly for the pooled samples underlying the 15- and 10-year-difference regressions.

The second-stage results for the main specification in columns (4), (6), and (8) indicate that there is a significantly positive effect of increases in overall immigration (all skill groups) on increases in FPÖ votes. The results do not depend on the particular time horizon over which the immigration change is measured. Like the prior results, these findings are robust to the inclusion or exclusion of covariates. ${ }^{35}$ Columns (3), (5), and (7) show that, when using percentage point changes on the left-hand and righthand sides of the regression, due to the weak first stage, the second-stage coefficient becomes implausibly large.

We report standardized beta coefficients to evaluate the quantitative importance of the estimated effects. The results in the main specification regressions (4), (6), and (8) imply that a one standard deviation increase in the dependent variable causes about a one tenth of a standard deviation increase in FPÖ vote shares. For comparison, column (2) shows the results from a fixed-effects estimation, using a log-log specification (which closely corresponds to the estimation in percent changes). Column (1) records the previously obtained result from the main fixed-effect regression specification, respectively. The standardized beta coefficients imply that the quantitative results of the IV-estimation match well with the estimates from either of the two panel fixed effects approaches.

A possible drawback of the percent change specification is that the further away one moves from the mean immigrant or FPÖ vote share, the more the predicted effects on vote shares of the same percentage point increase in the immigrant share will vary. Because the first stage in the percentage point specification is too weak, we cannot directly compare the quantitative effects for the two IV approaches. In analyses available on request, the percentage point specifications and the $\log -\log$ specifications yield quite similar quantitative predictions in the fixed effects models. However, the log-log specification creates a somewhat larger residual variance, which supports using the percentage-point specification in the fixed effect regressions presented in Section 4. In the IV setting, the percent-change specification is the only viable option in light of the stronger first stage that obtains with this approach. Overall, IV approach and the previous fixed effects approach yield a consistent picture: the relationship between

35. See Table B.2 in Online Appendix B. We have also analyzed second-stage results for changes between individual years. All individual differences show a positive relationship between changes in immigration changes in FPÖ voting, and most (though not all) individual differences are statistically significant. The effect of immigration is somewhat bigger when considering changes in the more recent 15 years than in the first 15 years, though the confidence intervals are overlapping. These findings are available on request. Moreover, we have omitted outliers in terms of predicted percent changes in immigrant shares. The results are unaffected. 
the regional immigrant inflow and the regional increase in FPÖ votes is statistically significant and quantitatively important.

Heterogeneous Effects by Immigrant Groups. Table 9 reports results for low-skilled and high-skilled immigration separately. The table also contains the overall results for comparison. For low-skilled workers, we find results consistent with the panel fixed effect estimates: Increases in low-skilled immigration are significantly associated with increases in FPO votes (in the 20+ year regressions, the effect is positive but not significant). For high-skilled immigration, we find negative point estimates throughout, though the second-stage estimates are not statistically significant. The first stages generally perform well for both low- and high-skilled immigration changes. ${ }^{36}$

Heterogeneous Effects across Communities. In Table 10, we present IV-estimates splitting the sample by the same set of variables (that potentially interact with immigration in explaining FPÖ votes) as in Table 5. We present results for the 15year changes. (First-stage results were strongest for this time difference, increasing the chance to obtaining useful first stages also in split samples. Indeed, 13 out of 16 first-stage regressions yield Kleibergen-Paap statistics of above 10, despite the much smaller samples.)

Panels A and B of Table 10 show that the strongest impact of immigrant inflows on far-right voting occurs in Austrian communities with high unemployment and in communities where native-immigrant labor market competition is high. Panel C documents that the effect of immigration is larger in communities with a large share of highly educated Austrians. The sample split according to the number of immigrant children does not yield quite the same picture as before (see Panel D). However, the strongest effect does again occur in the highest quartile of immigrant children presence. Overall, these results are in line with the findings from the panel fixed effects estimations, although in the IV analysis the differences across groups are less significant. In sum, the findings provide support for the conclusion that voter worries about both labor market effects and compositional amenities may be important in explaining the increase in FPÖ votes.

Effects on Compositional Amenities. Finally, Table 11 presents IV results on other outcomes (availability of public childcare, school commuting) that might be detrimentally affected by an increase in immigration and hence might partly induce voters to lean toward an anti-immigration far-right political party.

Consistent with the panel fixed effect regressions, we find strong evidence that afternoon care is less likely to be made available in communities with substantial lowskilled immigration. We also find similar results for day nurseries in the IV regressions.

36. We separately instrument the two immigration types because we had found some evidence earlier that there is a slight migration response to high-skilled immigration. When we jointly instrument both low/and high-skill immigration by the respective changes in the predicted shares for the respective years, we obtain stronger results. These findings are available on request. 


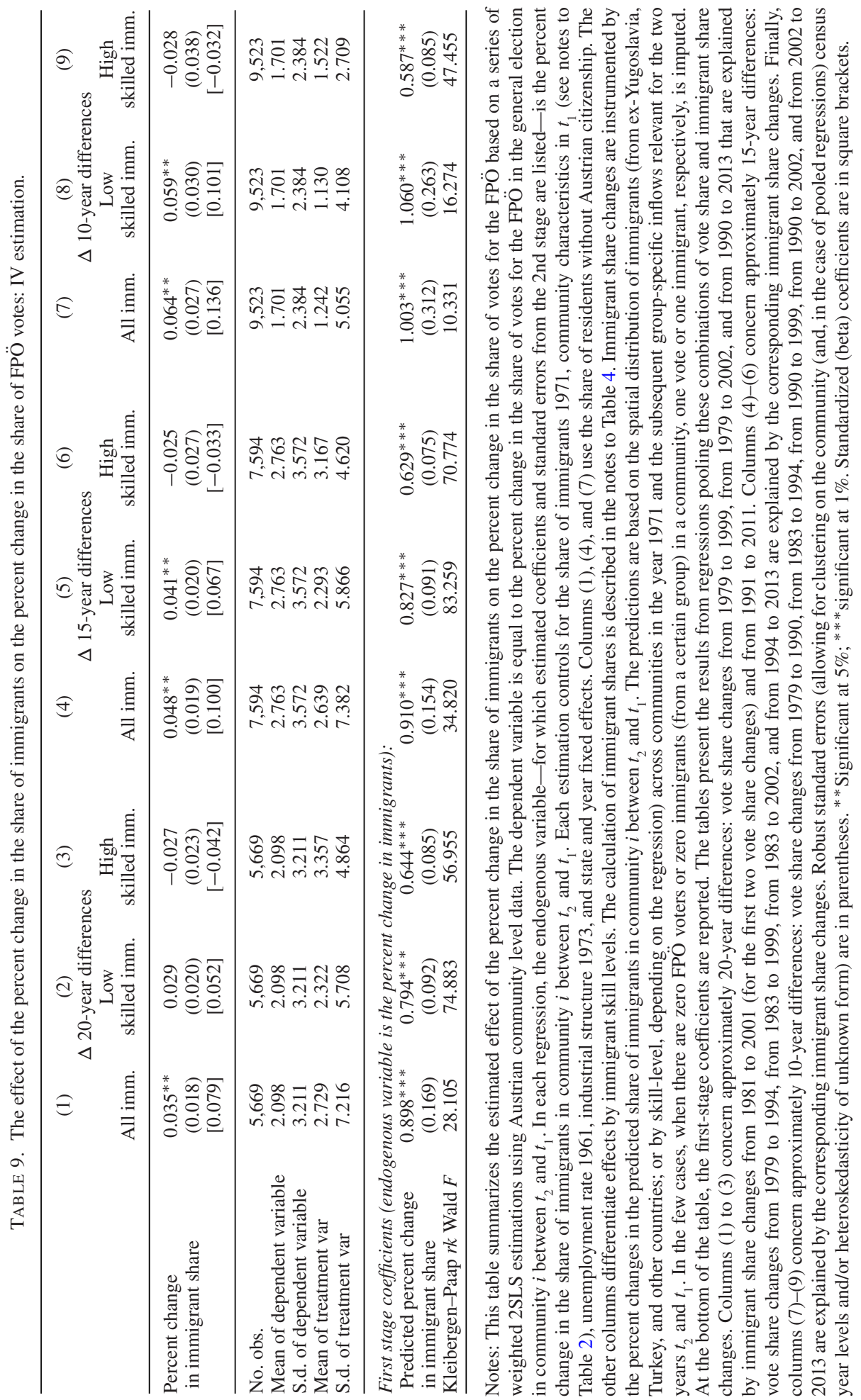


TABLE 10. The role of labor market concerns and of compositional amenities for the effect of the change in the share of immigrants on the change in the share of FPÖ votes: IV estimation.

\begin{tabular}{|c|c|c|c|c|c|c|}
\hline Sample split criterion & $\begin{array}{l}\text { (1) } \\
\text { Below } \\
\text { 25th } \\
\text { percentile }\end{array}$ & $\begin{array}{l}\text { (2) } \\
\text { Below } \\
\text { 50th } \\
\text { percentile }\end{array}$ & $\begin{array}{l}\text { (3) } \\
\text { Above } \\
\text { 50th } \\
\text { percentile }\end{array}$ & $\begin{array}{l}\text { (4) } \\
\text { Above } \\
\text { 75th } \\
\text { percentile }\end{array}$ & $\begin{array}{l}(5) \\
t \text {-stati } \\
\text { for the } \\
(1)=(4)\end{array}$ & $\begin{array}{l}\quad(6) \\
\text { stics }^{\mathrm{a}} \\
\text { test of: } \\
(2)=(3)\end{array}$ \\
\hline \multicolumn{7}{|c|}{ Panel A: Unemployment rate of natives } \\
\hline $\begin{array}{l}15 \text {-year percent change } \\
\text { in the immigrant share }\end{array}$ & $\begin{array}{c}0.054 \\
(0.049) \\
{[0.166]}\end{array}$ & $\begin{array}{l}0.033 \\
(0.029) \\
{[0.084]}\end{array}$ & $\begin{array}{c}0.056^{* *} \\
(0.025) \\
{[0.092]}\end{array}$ & $\begin{array}{c}0.117^{* * *} \\
(0.037) \\
{[0.148]}\end{array}$ & $\begin{array}{c}1.026 \\
\{0.305\}\end{array}$ & $\begin{array}{c}0.611 \\
\{0.541\}\end{array}$ \\
\hline $\begin{array}{l}\text { Mean of dep var } \\
\text { Mean of split var } \\
\text { Kleibergen-Paap } r k \text { Wald } F\end{array}$ & $\begin{array}{c}2.912 \\
0.032 \\
48.824\end{array}$ & $\begin{array}{c}3.118 \\
0.035 \\
17.947\end{array}$ & $\begin{array}{c}2.626 \\
0.055 \\
15.687\end{array}$ & $\begin{array}{l}2.612 \\
0.065 \\
6.950\end{array}$ & & \\
\hline $\begin{array}{l}\text { Panel B: Labor market comp } \\
\text { 15-year percent change } \\
\text { in the immigrant share }\end{array}$ & $\begin{array}{l}\text { etition } \\
\qquad 0.011 \\
(0.017) \\
{[0.039]}\end{array}$ & $\begin{array}{c}0.027 \\
(0.017) \\
{[0.067]}\end{array}$ & $\begin{array}{l}0.066^{*} \\
(0.040) \\
{[0.109]}\end{array}$ & $\begin{array}{l}0.053 \\
(0.034) \\
{[0.095]}\end{array}$ & $\begin{array}{c}1.112 \\
\{0.266\}\end{array}$ & $\begin{array}{c}0.893 \\
\{0.372\}\end{array}$ \\
\hline $\begin{array}{l}\text { Mean of dep var } \\
\text { Mean of split var } \\
\text { Kleibergen-Paap } r k \text { Wald } F\end{array}$ & $\begin{array}{c}4.153 \\
0.977 \\
10.320\end{array}$ & $\begin{array}{c}3.303 \\
0.989 \\
14.937\end{array}$ & $\begin{array}{c}2.564 \\
1.003 \\
42.761\end{array}$ & $\begin{array}{c}2.548 \\
1.003 \\
25.433\end{array}$ & & \\
\hline $\begin{array}{l}\text { Panel C: Educational attainn } \\
15 \text {-year percent change } \\
\text { in the immigrant share }\end{array}$ & $\begin{array}{l}\text { nent of native } \\
\quad-0.014 \\
\quad(0.040) \\
{[-0.031]}\end{array}$ & $\begin{array}{l}0.013 \\
(0.020) \\
{[0.035]}\end{array}$ & $\begin{array}{l}0.059^{*} \\
(0.032) \\
{[0.092]}\end{array}$ & $\begin{array}{c}0.085^{* * *} \\
(0.025) \\
{[0.086]}\end{array}$ & $\begin{array}{c}2.032 \\
\{0.042\}\end{array}$ & $\begin{array}{c}1.213 \\
\{0.225\}\end{array}$ \\
\hline $\begin{array}{l}\text { Mean of dep var } \\
\text { Mean of split var } \\
\text { Kleibergen-Paap } r k \text { Wald F }\end{array}$ & $\begin{array}{l}4.595 \\
1.608 \\
6.806\end{array}$ & $\begin{array}{c}3.944 \\
1.663 \\
13.982\end{array}$ & $\begin{array}{c}2.494 \\
1.876 \\
90.227\end{array}$ & $\begin{array}{c}2.292 \\
1.953 \\
19.359\end{array}$ & & \\
\hline $\begin{array}{l}\text { Panel D: Ratio of immigrant } \\
\text { 15-year percent change } \\
\text { in the immigrant share }\end{array}$ & kids to all kic & $\begin{array}{l}d s \\
\quad 0.033 \\
(0.021) \\
{[0.094]}\end{array}$ & $\begin{array}{l}0.061 \\
(0.103) \\
{[0.030]}\end{array}$ & $\begin{array}{c}0.229 \\
(0.199) \\
{[0.074]}\end{array}$ & $\begin{array}{l}0.977^{\mathrm{b}} \\
\{0.329\}\end{array}$ & $\begin{array}{c}0.266 \\
\{0.791\}\end{array}$ \\
\hline $\begin{array}{l}\text { Mean of dep var } \\
\text { Mean of split var } \\
\text { Kleibergen-Paap } r k \text { Wald } F\end{array}$ & & $\begin{array}{c}3.950 \\
0.030 \\
28.688\end{array}$ & $\begin{array}{l}2.441 \\
0.071 \\
60.792\end{array}$ & $\begin{array}{c}2.298 \\
0.096 \\
37.130\end{array}$ & & \\
\hline
\end{tabular}

Notes: This table summarizes IV-estimations equivalent to those presented in column (4) of Table 9 for different subsamples. In each panel, the split variable is stated at the header. The columns (1)-(4) indicate sample splits at the first quartile, the median, and the third quartile of the variable stated at the header of each column. Splits are conducted according to the distribution of the respective variable observed in 1981. The construction of the labor market competition index (Panel B) follows Card (2001) and is explained in detail in the text. Average educational attainment of natives (Panel C) is based on a four-point scale, drawing on the four levels of education described in the data section. All regressions include the same set of controls as the estimations summarized in Table 9. Robust standard errors (allowing for clustering on the community level and/or heteroskedasticity of unknown

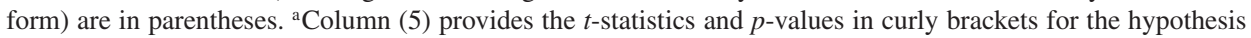
that the coefficients of interest in the subsamples from columns (1) and (4) are identical. Column (6) provides the $t$-statistics and $p$-values in curly brackets for the hypothesis that the coefficients of interest in the subsamples from columns (2) and (3) are identical. All $t$-statistics are based on fully interacted models using the respective pooled samples and report the $t$-statistic on the coefficient on the interaction term between the share of immigrants and a binary indicator for the second sample. ${ }^{\mathrm{b}}$ In the case of Panel D, columns (2) and (4) are compared. * Significant at $10 \%{ }^{* *}$ significant at $5 \% ;{ }^{* *}$ significant at $1 \%$. Standardized (beta) coefficients are in square brackets. 


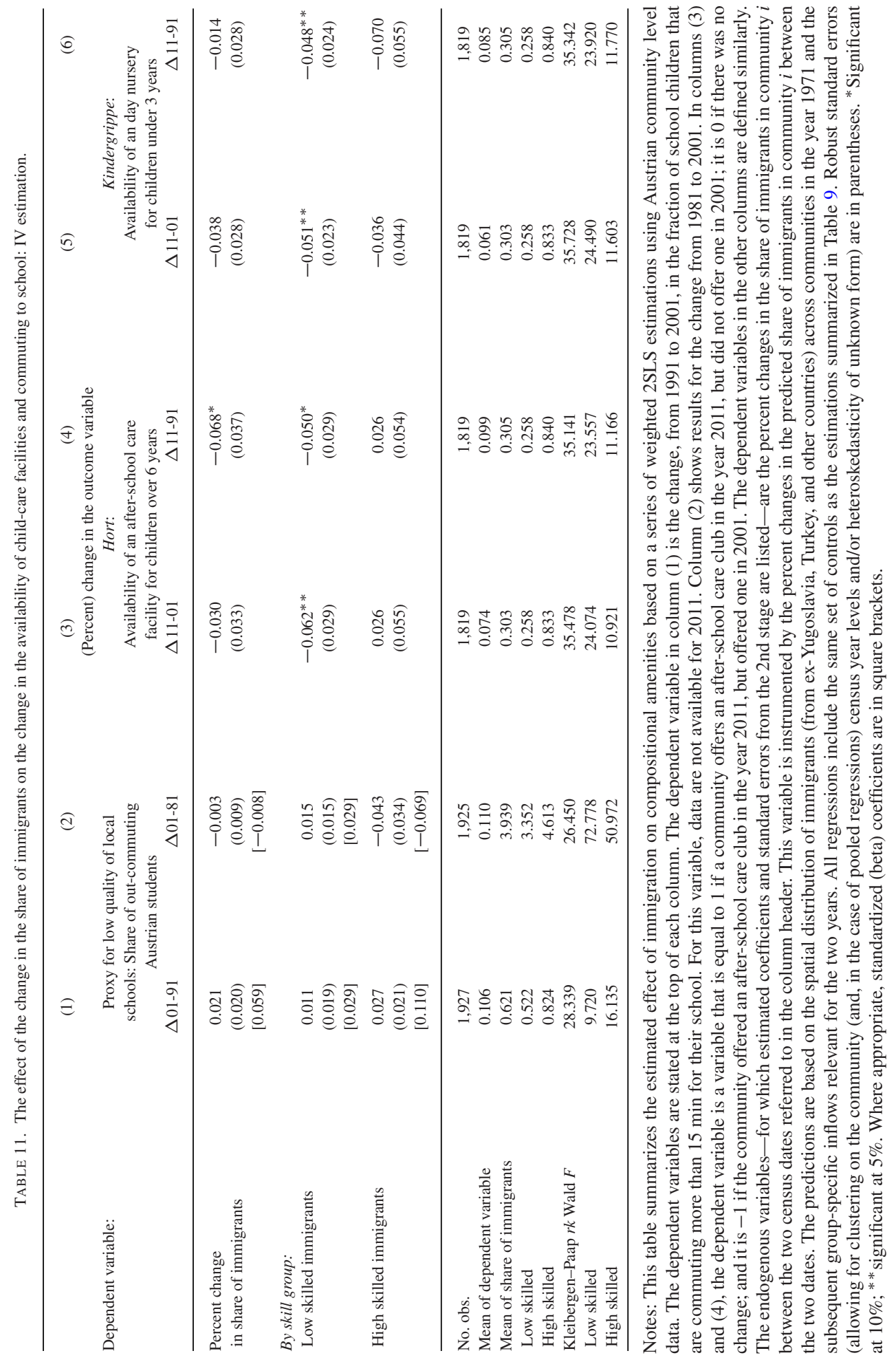


By contrast, using the IV strategy, we do not obtain significant evidence of an effect of immigration on the tendency of Austrian parents sending their children to nonlocal schools.

Overall, a broadly similar picture as in the fixed effects regression emerges. There is suggestive, but not extremely strong evidence of negative effects of immigration on the compositional amenities. As mentioned earlier, the various amenities considered here are by no means an exhaustive list but should be considered as potentially relevant examples. Immigration may drive political preferences through affecting other amenities such as the housing market, crime, or environmental quality (that we did not consider here due to lack of appropriate data). Future work should explore where these additional types of amenities are relevant for far-right voting.

\section{Conclusions}

International migration flows have been strongly increasing over the last decades. The United Nations (2016) report 244 million international migrants worldwide (76 million in Europe) in 2015, up from 173 million (56 million in Europe) in 2000, with the largest increase in high-income countries. The large immigration flows and the way policy should react to them have always been important policy topics. This is even more so in the face of the current influx of refugees into Europe, where immigration now arguably ranks highest on the policy agenda. What are the political consequences of increased immigration and how does it affect voting behavior of the electorate?

Political folklore holds that far-right parties attract voters by appealing to antiimmigration sentiments of the voting native population. Yet, it is also possible that more contact with immigrants could foster better understanding and ultimately a more positive attitude of voters. Although existing empirical studies often show a positive correlation between immigration and votes for far-right political parties, empirical evidence establishing a causal link is still scarce.

This paper studies the effect of the increasing presence of immigrants in one's neighborhood on the change in election support for the far right. We look at the Freedom Party of Austria (FPÖ) that, under the leadership of Jörg Haider, increased its vote share from less than $5 \%$ in the early 1980 s to $27 \%$ in the late 1990 s. The FPÖ obtained more than $20 \%$ of the vote in 2013. In the December 2016 Presidential election runoff, the FPÖ candidate lost, though he received $46.2 \%$ of the votes.

We establish the following results. First, we find that a tenth of the cross-community variation in the increase of (FPÖ) vote shares over time can be attributed to crosscommunity variation in the inflow of immigrants. Our second result shows that the composition of immigrants affects voting decisions. We document that lowand medium-skilled immigration causes Austrian voters to turn to the far right, whereas more high-skilled immigration either has an insignificant or a negative effect on FPÖ votes. We caution that education levels can capture many dimension and that communities with differing skill levels of immigrants may differ along other dimensions. Third, the results are likely due to both perceived labor market competition 
and a concern that immigration imposes negative externalities associated with the composition of neighborhoods, workplaces, and schools. The effects of immigration are stronger where unemployment among natives is high and where labor market competition between natives and immigrants is high, and they are also stronger where there are many immigrant children and where natives are highly educated. These results are consistent with the labor market channel and with the compositional amenities channel. Fourth, there is suggestive evidence that immigration is associated with a lower availability of childcare and makes Austrian kids more likely to commute longer distances to school. This is consistent with the claim that Austrian voters worry about the impact of immigration on compositional amenities. The set of relevant amenities is clearly much broader than those considered here. Future research should try to better understand which channels drive anti-immigration sentiments and voting for anti-immigration parties.

Immigration is necessary for developed countries, as persistently low fertility rates and increases in life expectancy let societies age. However, immigration is not a smooth process, and it can generate tensions and conflicts. Our paper shows that the geographic proximity of immigrants is an important driver of support for antiimmigration far-right parties. Interestingly, in our analysis we found neither tipping points nor a leveling-off phenomenon. Thus, if policies remain unchanged, a further influx of immigrants into a community tends to continue to increase the vote share of the far right. Importantly, low-skill immigration is seen as more problematic by voters than high-skill immigration. A policy implication of this result is that fostering high-skilled immigration or the education of currently low-skilled immigrants may be important also from the point of view of political stability. Another conclusion of our analysis is that policies mitigating (perceived or true) negative effects on compositional amenities by fostering the integration of immigrants into local communities may be particularly important.

\section{References}

Allport, Gordon W. (1954). The Nature of Prejudice. Addison-Wesley, Cambridge, MA.

Almond, Gabriel and Sidney Verba (1965). The Civic Culture. Little, Brown, Boston.

Altonji, Joseph and David Card (1991). "The Effects of Immigration on the Labor Market Outcomes of Natives." In Immigration, Trade, and the Labour Market, edited by John M. Abowd and Richard B. Freeman. University of Chicago Press for NBER, Chicago, pp. 201-234.

Arzheimer, Kai (2009). "Contextual Factors and the Extreme Right Vote in Western Europe, 1980 2002." American Journal of Political Science, 53, 259-275.

Arzheimer, Kai and Elisabeth Carter (2006). "Political Opportunity Structures and Right-Wing Extremist Party Success." European Journal of Political Research, 45, 419-443.

Åslund, Olof (2005). "Now and Forever? Initial and Subsequent Location Choices of Immigrants." Regional Science and Urban Economics, 35, 141-165.

Barone, Guglielmo, Alessio D'Ignazio, Guido de Blasio, and Paolo Naticchioni (2016). "Mr. Rossi, Mr. Hu and Politics: The Role of Immigration in Shaping Natives' Voting Behavior." Journal of Public Economics, 136, 1-86.

Bartel, Ann P. (1989). "Where Do the New United States Immigrants Live?" Journal of Labor Economics, 7, 371-391. 
Bianchi, Milo, Paolo Buonanno, and Paolo Pinotti (2012). "Do Immigrants Cause Crime?" Journal of the European Economic Association, 10, 1318-1347.

Bisin, Alberto, Eleonora Patacchini, Thierry Verdier, and Yves Zenou (2008). "Are Muslim Immigrations Different in Terms of Cultural Integration?" Journal of the European Economic Association, 6, 445-456.

Bock-Schappelwein, Julia, Christoph Bremberger, Robert Hierlaender, Peter Huber, Kaethe Knittler, Johannes Berger, Helmut Hofer, Michael Miess, and Ludwig Strohner (2008). "Die oekonomischen Wirkungen der Immigration in Oesterreich 1989-2007.” WIFO Vienna.

Borjas, George J. (2003). "The Labor Demand Curve Is Downward Sloping: Reexamining the Impact of Immigration on the Labor Market." Quarterly Journal of Economics, 118, 1335-1374.

Borjas, George J. (2009). "The Analytics of the Wage Effect of Immigration.” NBER Working Paper 14796, National Bureau of Economic Research, Cambridge, MA.

Brunner, Beatrice and Andreas Kuhn (2014). "Immigration, Cultural Distance and Natives' Attitudes Towards Immigrants: Evidence from Swiss Voting Results." IZA Discussion Paper 8409, Institute for the Study of Labor, Bonn, Germany.

Calvó-Armengol, Antoni and Matthew O. Jackson (2004). "The Effects of Social Networks on Employment and Inequality." American Economic Review, 94(3), 426-454.

Card, David (2001). "Immigrant Inflows, Native Outflows, and the Local Labor Market Impacts of Higher Immigration.” Journal of Labor Economics, 19, 22-64.

Card, David (2005). "Is the New Immigration Really So Bad?" Economic Journal, 115, F300-F323.

Card, David (2007). "How Immigration Affects US Cities." CReAM Discussion Paper 11, Centre for Research and Analysis of Migration, London.

Card, David (2009). "Richard T. Ely Lecture: Immigration and Inequality". American Economic Review, 99(2), 1-21.

Card, David, Christian Dustmann, and Ian Preston (2012). "Immigration, Wages, and Compositional Amenities." Journal of the European Economic Association, 10, 78-119.

Citrin, Jack, Donald P. Green, Christopher Muste, and Cara Wong (1997). "Public Opinion Toward Immigration Reform: The Role of Economic Motivations." Journal of Politics, 59, 858-881.

Cortes, Patricia (2008). "The Effect of Low-skilled Immigration on US Prices: Evidence from CPI Data." Journal of Political Economy, 116, 381-422.

Dahl, Robert A. (1989). Democracy and Its Critics. Yale University Press, New Haven.

Dahlberg, Matz, Karin Edmark, and Heléne Lundqvist (2012). "Ethnic Diversity and Preferences for Redistribution." Journal of Political Economy, 120, 41-76.

Damm, Anna P. (2009). "Ethnic Enclaves and Immigrant Labor Market Outcomes: QuasiExperimental Evidence." Journal of Labor Economics, 27, 281-314.

de Bromhead, Alan, Barry Eichengreen, and Kevin H. O'Rourke (2013). "Political Extremism in the 1920s and 1930s: Do the German Lessons Generalize?" Journal of Economic History, 73, 371-406.

Downs, Anthony (1957). An Economic Theory of Democracy. Harper and Row, New York.

Dülmer, Herman and Markus Klein (2005). "Extreme Right-wing Voting in Germany in a Multilevel Perspective: A Rejoinder to Lubbers and Scheepers.” European Journal of Political Research, 44, 243-263.

Dustmann, Christian and Francesca Fabbri (2003). "Language Proficiency and Labour Market Performance of Immigrants in the UK." Economic Journal, 113, 695-717.

Dustmann, Christian and Ian P. Preston (2004). "Is Immigration Good or Bad for the Economy? Analysis of Attitudinal Responses." Research in Labour Economics, 24, 3-34.

Dustmann, Christian and Ian P. Preston (2007). "Racial and Economic Factors in Attitudes to Immigration." The B.E. Journal of Economic Analysis \& Policy: Advances, 7, Article 62.

Dustmann, Christian, Francesca Fabbri, and Ian Preston (2005). "The Impact of Immigration on the British Labour Market." Economic Journal, 115, F324-F341.

Edin, Per-Anders, Peter Fredriksson, and Olof Åslund (2003). "Ethnic Enclaves and the Economic Success of Immigrants: Evidence from a Natural Experiment." Quarterly Journal of Economics, 118, 329-357. 
Facchini, Giovanni and Anna Maria Mayda (2009). "Does the Welfare State Affect Individual Attitudes Toward Immigrants? Evidence Across Countries." Review of Economics and Statistics, 91, 295-314.

Facchini, Giovanni and Max Steinhardt (2011). "What Drives US Immigration Policy? Evidence from Congressional Roll Call Votes." Journal of Public Economics, 95, 734-743.

Facchini, Giovanni, Anna Maria Mayda, and Prachi Mishra (2011). "Do Interest Groups Affect US Immigration Policy?" Journal of International Economics, 85, 114-128.

Gerdes, Christer and Eskil Wadensjö (2008). "The Impact of Immigration on Election Outcomes in Danish Municipalities." IZA Discussion Paper 3586, Institute for the Study of Labor, Bonn, Germany.

Glaeser, Edward L. (2005). “The Political Economy of Hatred.” Quarterly Journal of Economics, $120,45-86$.

Glitz, Albrecht (2012). "The Labor Market Impact of Immigration: A Quasi-Experiment Exploiting Immigrant Location Rules in Germany." Journal of Labor Economics, 20, 175-213.

Golder, Martin (2003). "Explaining Variation in the Success of Extreme Right-Wing Parties in Western Europe." Comparative Political Studies, 36, 432-466.

Hainmueller, Jens and Michael J. Hiscox (2007). "Educated Preferences: Explaining Attitudes Toward Immigration in Europe." International Organization, 61, 399-442.

Hainmueller, Jens and Michael J. Hiscox (2010). "Attitudes toward Highly Skilled and Low Skilled Immigration: Evidence from a Survey Experiment." American Political Science Review, 104, 61-84.

Harmon, Nikolaj A. (2015). "Immigration, Ethnic Diversity and Political Outcomes: Evidence from Denmark." Unpublished manuscript, University of Copenhagen.

Horvath, Thomas (2011). "Immigration and the Distribution of Wages in Austria." Economics Working Papers 2011-11, Johannes Kepler University Linz, Austria.

Ioannides, Yannis M. and Linda Datcher Loury (2004). "Job Information Networks, Neighborhood Effects, and Inequality." Journal of Economic Literature, 42, 1056-1093.

Jackman, Robert W. and Karin Volper (1996). "Conditions Favouring Parties of the Extreme Right in Western Europe." British Journal of Political Science, 26, 501-521.

Jaeger, David A. (2007). "Green Cards and the Location Choices of Immigrants in the United States, 1971-2000.” Research in Labor Economics, 27, 131-183.

King, Gary, Ori Rosen, Martin Tanner, and Alexander F. Wagner (2008). "Ordinary Economic Voting Behavior in the Extraordinary Election of Adolf Hitler." Journal of Economic History, 68, 951-996.

Knigge, Pia (1998). "The Ecological Correlates of Right-Wing Extremism in Western Europe." European Journal of Political Research, 34, 249-279.

Krishnakumar, Jaya and Tobias Müller (2012). "The Political Economy of Immigration in a Direct Democracy: The Case of Switzerland." European Economic Review, 56, 174-189.

Lazear, Edward P. (1999). "Culture and Language." Journal of Political Economy, 107, S95-S126.

Lubbers, Marcel and Peer Scheepers (2000). "Individual and Contextual Characteristics of the German Extreme Right-Wing Vote in the 1990s. A Test of Complementary Theories." European Journal of Political Research, 38, 63-94.

Lubbers, Marcel, Mérove Gijsberts, and Peer Scheepers (2002). "Extreme Right-wing Voting in Western Europe." European Journal of Political Research, 41, 345-378.

Malgouyres, Clément (2014). "The Impact of Exposure to Low-Wage Country Competition on Votes for the Far-Right: Evidence from French Presidential Elections." Unpublished manuscript, European University Institute, Italy, Florence.

Mayda, Anna Maria, Giovanni Peri, and Walter Steingress (2015). "Immigration to the U.S.: A Problem for the Republicans or the Democrats?" IZA Discussion Paper 9543, Institute for the Study of Labor, Bonn, Germany.

Montgomery, James D. (1991). "Social Networks and Labor-Market Outcomes: Toward an Economic Analysis.” American Economic Review, 81(5), 1408-1418.

Mudde, Cas (1996). "The War of Words. Defining the Extreme Right Party Family." West European Politics, 19, 225-248. 
Munshi, Kaivan (2003). "Networks in the Modern Economy: Mexican Migrants in the U.S. Labor Market." Quarterly Journal of Economics, 118, 549-599.

Nannestad, Peter and Martin Paldam (1995). "The VP-Function: A Survey of the Literature on Vote and Popularity Functions After 25 Years." Public Choice, 79, 213-245.

O'Rourke, Kevin H. and Richard Sinnott (2006). "The Determinants of Individual Attitudes towards Immigration." European Journal of Political Research, 22, 838-861.

Otto, Alkis Henri and Max Friedrich Steinhardt (2014). "Immigration and Election Outcomes Evidence from City Districts in Hamburg." Regional Science and Urban Economics, 45, 67-79.

Peri, Giovanni and Chad Sparber (2011). "Assessing Inherent Model Bias: An Application to Native Displacement in Response to Immigration." Journal of Urban Economics, 69, 82-91.

Saiz, Albert (2007). "Immigration and Housing Rents in American Cities." Journal of Urban Economics, 61, 345-371.

Scheve, Kenneth F. and Matthew J. Slaughter (2001). "Labor Market Competition and Individual Preferences Over Immigration Policy." Review of Economics and Statistics, 83, 133-145.

Speciale, Biagio (2012). "Does Immigration Affect Public Education Expenditures? Quasiexperimental Evidence." Journal of Public Economics, 96, 773-783.

Spolaore, Enrico and Romain Wacziarg (2013). "How Deep Are the Roots of Economic Development." Journal of Economic Literature, 51, 1-45.

Staiger, Douglas and James H. Stock (1997). "Instrumental Variables Regression with Weak Instruments." Econometrica, 65, 557-586.

Steinmayr, Andreas (2016). "Exposure to Refugees and Voting for the Far-Right: (Unexpected) Results from Austria." IZA Discussion Paper 9790, Institute for the Study of Labor, Bonn, Germany.

Stock, James H., Jonathan H. Wright, and Motohiro Yogo (2002). "A Survey of Weak Instruments and Weak Identification in Generalized Method of Moments." Journal of Business and Economics Statistics, 20, 518-529.

United Nations (2016). International Migration Report 2015. Department of Economic and Social Affairs, Population Division, New York.

Voigtländer, Nico and Hans-Joachim Voth (2012). "Persecution Perpetuated: The Medieval Origins of Anti-Semitic Violence in Nazi Germany.” The Quarterly Journal of Economics, 127, 1339-1392.

WIFO, Wirtschaftsforschungsinstitut (1963). "Das Fremdarbeiter-Kontingent in Österreich.” WIFOHeft, 11, 411-415.

Winter-Ebmer, Rudolf and Josef Zweimüller (1996). "Immigration and the Earnings of Young Native Workers." Oxford Economic Papers, 48, 473-491.

Winter-Ebmer, Rudolf and Josef Zweimüller (1999). "Do Immigrants Displace Native Workers?" Journal of Population Economics, 12, 327-340.

\section{Supplementary Data}

Supplementary data are available at JEEA online. 